\title{
Tidal deposits in the Early Miocene Central Paratethys: the Vučji Jarek and Čemernica members of the Macelj formation (NW Croatia)
}

\author{
Radovan Avanić ${ }^{1}$, Davor Pavelić ${ }^{2}$, Zoltan Pécskay ${ }^{3}$, Mirjana Miknić ${ }^{1}$, Darko Tibljaš ${ }^{4}$ and Lara Wacha ${ }^{1}$ \\ ${ }^{1}$ Croatian Geological Survey, Department of Geology, Sachsova 2, HR-10000 Zagreb, Croatia \\ 2 University of Zagreb, Faculty of Mining, Geology and Petroleum Engineering, Pierottijeva 6, HR-10000 Zagreb, Croatia \\ ${ }^{3}$ Institute for Nuclear Research, Isotope Climatology and Environmental Research Centre (ICER), K-Ar group, Bem tér 18/c 4026, HU-4030 Debrecen, Hungary \\ ${ }^{4}$ University of Zagreb, Faculty of Science, Horvatovac 95, HR-10000 Zagreb, Croatia
}

doi: $10.4154 / g c .2021 .06$

Article history:

Manuscript received June 02, 2020

Revised manuscript accepted February 16, 2021

Available online February 28, 2021
Keywords: Macelj formation, Vučji Jarek member Čemernica member, tidal deposits, K-Ar dating, Eggenburgian, Hrvatsko Zagorje Basin, Central Paratethys

\begin{abstract}
The Macelj formation is an informal Eggenburgian-early Ottnangian lithostratigraphic unit that is established in the area of the Hrvatsko Zagorje Basin, which represented a marginal zone of the Early Miocene Central Paratethys Sea. Modern studies, as a part of the Geologic Map of the Republic of Croatia 1:50 000 project, yielded new data that improves the knowledge of the depositional and stratigraphic characteristics of the formation. The sedimentological research within this study was focused on the two older lithostratigraphic units of the Macelj formation: the Vučji Jarek member and the Čemernica member. The Vučji Jarek mb. is represented by three facies. The Facies of horizontally bedded sandstones is characterized by mostly medium-grained, moderately sorted sandstones that reflect deposition on the foreshore to the upper shoreface. The Facies of horizontally and cross-bedded glauconitic sandstones is composed of fine- to coarsegrained, well-sorted sandstones that indicate foreshore to shoreface deposition under tidal influence. The Facies of horizontally and cross-bedded pyroclastics consists of tuff, pumice, lapilli and large blocks, showing a chaotic structure in places. Deposition occurred at the shoreface under tidal influence. The Čemernica mb. is represented by the Facies of structureless clayey-silty sands that are poorly sorted and bioturbated, and indicates deposition below the fairweather wavebase, in the offshore-transition zone. Deposits of the members include marine macro- and microfossil associations.

$\mathrm{K}$-Ar dating of separated glauconite mineral fractions yielded an early Eggenburgian age for the Vučji Jarek mb. glauconitic sandstones $(19.2 \pm 0.64 \mathrm{Ma})$ which is in accordance with biostratigraphical analyses. Sedimentological characteristics of the Eggenburgian Macelj fm., especially those that reflect the tidal influence, fit the general characteristics of the Central Paratethys Sea in the Early Miocene.
\end{abstract}

\section{INTRODUCTION}

The lower Miocene Macelj formation was described and mapped in eastern Slovenia and the northwestern part of the Hrvatsko Zagorje Basin (HZB) in Croatia (ŠIMUNIĆ, AN. et al., 1995; ANIČIĆ \& JURIŠA, 1984, 1985; ANIČIĆ et al., 2002; Fig. 1A). It was deposited in shallow marine and deltaic sedimentary environments (AVANIĆ, 2012) on the southern margin of the Eggenburgian Central Paratethys sea (RÖGL \& STEININGER, 1983; PILLER et al., 2007; HARZHAUSER \& PILLER, 2007; PAVELIĆ, 2001; KOVÁĆ et al., 2017), and it reflects specific, mostly tidal depositional conditions. In Croatia, it is distributed in the area between Mts. Strahinščica and Ivanščica in the south and Ravna gora in the northeast, bounded by the Sutla River in the west and Bednja in the east (Fig. 1A). These deposits are about 300-350 m thick and consist of the so-called Macelj sandstones, i.e. glauconitic sandstones, conglomerates, siltstones, pelites and pyroclastics (ŠIMUNIĆ, AN. et al., 1995). The Macelj fm. was subdivided into three members based on detailed analysis of measured geological columns and mapping; the Vučji Jarek mb, the Čemernica mb. and the Lipni Vrh mb. (ŠIMUNIĆ, AN. et al., 1995). More recent researches proposed a further member, i.e. the Vrbno mb. (AVANIĆ et al., 2005; AVANIĆ, 2012) and as such, they were represented on recent geological maps (Fig. 2)
(AVANIĆ et al., 2015). Based on the fossil association, deposits of the Macelj fm. belong to the Eggenburgian-early Ottnangian (ŠIMUNIĆ, AN. et al., 1995; AVANIĆ, 2012). Nevertheless, systematic geochronological studies are still lacking. An accurate geochronological study based on radiometric dating might be expected to provide a better understanding related to such a sedimentary sequence and would be of significance to understanding the regional distribution of similar Early Miocene deposits in the Central Paratethys.

The Macelj formation has been the subject of many studies. In pioneering works, dominating sandstones were interpreted as shallow marine deposits, and named the Macelj sandstones (GORJANOVIĆ-KRAMBERGER, 1904a, b). Later, a mineralogical study of the Macelj sandstones indicated the origin of glauconitic material with the alteration of dacite-andesite volcanoclastic material in shallow-marine environments (TIŠLJAR \& ŠIMUNIĆ, 1978; ŠIMUNIĆ, AL. et al., 1990; TADEJ et al., 1997), while the provenance of the sandstones, interpreted as shallow marine deposits, was related to the suture belts, back-arc thrusted belts or magmatic arcs (ALJINOVIĆ et al., 2003). Sedimentological studies suggested the Macelj sandstones indicated deposition by the influence of tides (ŠIMUNIĆ, AL. et al., 1988, 1990; AVANIĆ et al., 2005; AVANIĆ, 2012). 

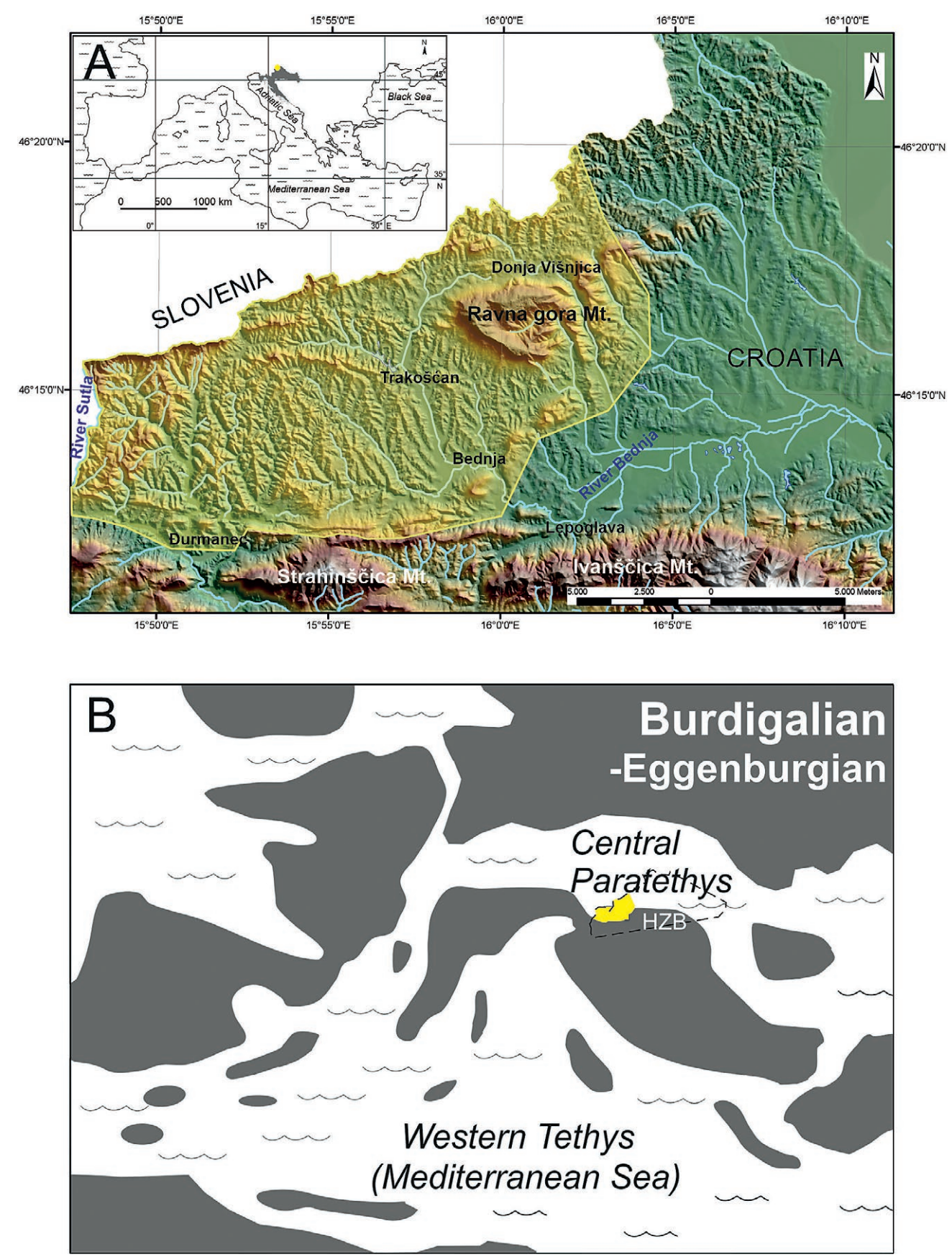

Figure 1. A Location map showing the NW part of Croatia. The study area is marked in yellow. The inset shows the geographic sketch of the Mediterranean area. The territory of Croatia is shaded and the study area is marked with a yellow dot. B Palaeogeographic sketch map of the circum-Mediterranean area with a focus on the Central Paratethys Sea in the Burdigalian-Eggenburgian (modified after HARZHAUSER \& PILLER, 2007) and the tentative position of the Hrvatsko Zagorje Basin (i.e. Hrvatsko Zagorje Bay - HZB).

The aim of this paper is to interpret the depositional mechanisms and environments of the Vučji Jarek mb. and Čemernica $\mathrm{mb}$. as the two older members of the Macelj fm., based on facies analysis, and reconstruction of the early Miocene palaeogeography of the HZB. Within this study geological mapping at the scale of 1:50.000 of the area between the Slovenian border and Strahinščica and Ivanščica Mts. in NW Croatia was performed accompanied with detailed sampling and analysis of most representative locations and outcrops (Fig. 2). A new geologic map is presented, with lithostratigraphic units categorized according to lithostratigraphic standards proposed by KORBAR et al. (2012).

Furthermore, for the first time, the chronological framework for the glauconite rich sediments is given and discussed based on $\mathrm{K}-\mathrm{Ar}$ dating applied to the separated monomineralic glauconite fraction. In addition, based on the presented data, their interpretation and geochronology, the formalisation of the Vučji Jarek, and Čemernica members and the formalization of the Macelj fm. itself is proposed, in accordance with SALVADOR (1994) and KORBAR et al. (2012).

Adverse field circumstances, including relatively small outcrops scattered throughout the HZB, and partially weathered deposits limited detailed studies in some places and resulted in a more general interpretation. However, the interpretation of the depositional environments and palaeogeographic reconstruction of the Macelj fm., together with new geochronologic data, will improve the knowledge of the sedimentary evolution of this part of the Central Paratethys, and enable regional sedimentological and stratigraphic correlation in the Early Miocene. 


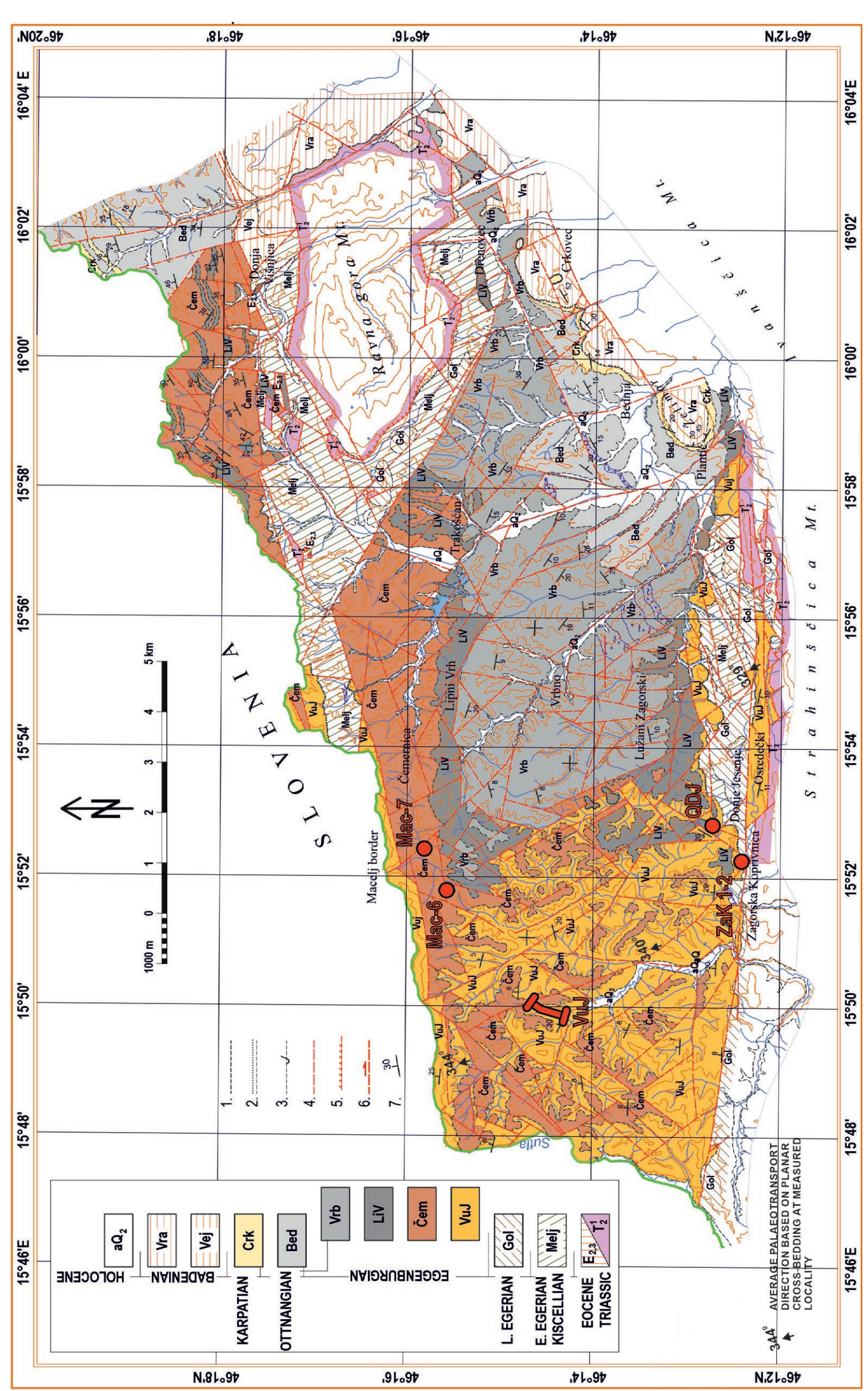

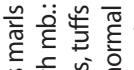

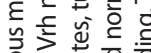

㟶

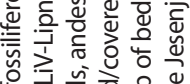
है

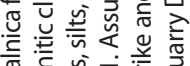

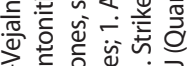

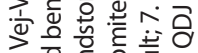

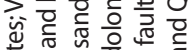
홍

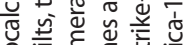

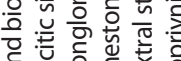
○)

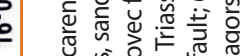
든

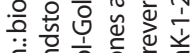
ह

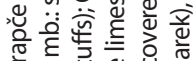
娄 穴定芯品

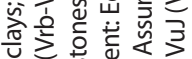

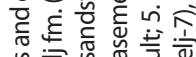

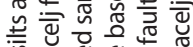

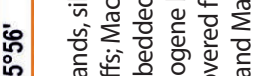
品 害它

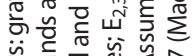

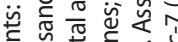

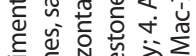
范 言

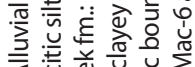
市 of

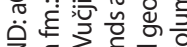

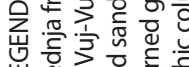
行 岁

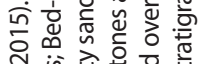

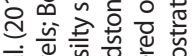

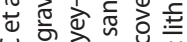

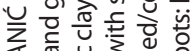

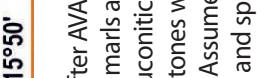

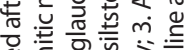
造

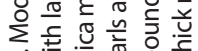
要专 कo

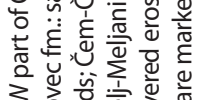

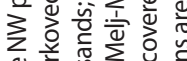

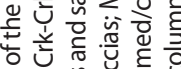

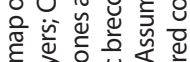
ह

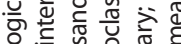

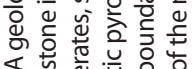
愹

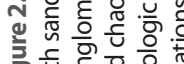

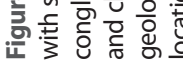




\section{GEOLOGICAL SETTING}

During the Miocene, the connection of the Central Paratethys with the world sea was established and lost several times. Marine transgressions, especially during the Early Miocene, did not flood the entire basin. This caused deposition in different environments characterized by a salinity change and evolution of endemic species, so the specific Central Paratethys evolution has necessitated the establishment of regional Miocene stages (Fig. 3A) (BÁLDI, 1980; RÖGL \& STEININGER, 1983; RÖGL, 1996, 1998; POPOV et al., 2004; HARZHAUSER \& PILLER, 2007; PILLER et al., 2007; SANT et al., 2017; KOVÁČ et al., 2018). In the early Miocene, the Central Paratethys was connected with the Western Tethys (i.e. the Mediterranean) and the North Sea and was mostly characterized by marine deposition (BÁLDI, 1980; RÖGL \& STEININGER, 1983; RÖGL, 1998; POPOV et al., 2004; HARZHAUSER \& PILLER, 2007; KOVÁČ et al., 2018). The Eggenburgian deposition was controlled by an anti-estuarine water regime, when evaporation exceeded the fresh-water input from precipitation and river discharge (KOVÁČ et al., 2017).

The Hrvatsko Zagorje Basin (HZB), situated in north-western Croatia (Fig. 1A and B), is an Early Miocene marginal sedimentary basin and an integral part of the Central Paratethyan realm (PAVELIĆ, 2001; AVANIĆ, 2012; PAVELIĆ \& KOVAČIĆ, 2018). After the disintegration of the Western Tethys into the Paratethys and the Mediterranean in the Late Eocene (BÁLDI, 1980; RÖGL \& STEININGER, 1983; RÖGL, 1996, 1998), a large area of north Croatia became land. Sedimentation continued to the Oligocene (i.e. Kiscellian, after BÁLDI, 1969; RÖGL \& STEININGER, 1983; PILLER et al., 2007) only in northwestern Croatia (ŠIMUNIĆ, AN. et al., 1981, 1982). After tectonic uplift, a new depositional cycle commenced in the Egerian-Eggenburgian, characterized by the transition from marine to brackish-water and back again to marine deposition, that was restricted to the NW part of Croatia, i.e. the HZB, the Mura Depression and the NW part of the Drava Depression (PAVELIĆ, 2001; AVANIĆ, 2012). The early Miocene deposition of the HZB strongly differs from the rest of north Croatia, i.e. from the rift-type North Croatian Basin (NCB), where sedimentation commenced in the Ottnangian and was characterized by fresh-water environments that passed into marine deposition in the early or middle Badenian (PAVELIĆ, 2001; ĆORIĆ et al., 2009; MALVIĆ, 2012; PAVELIĆ \& KOVAČIĆ, 2018; AVANIĆ et al., 2018a, b; BRLEK et al., 2018, 2020).

The evolution of the HZB was strongly controlled by volcanism and several phases of tectonic activity. Along relics of the previous subduction zone, Periadriatic-Vardar transform faults were generated during the Oligocene transpression phase, controlling the formation of the southern margin of the Central Paratethys. The early Miocene (Egerian-Eggenburgian) volcanism was the first post-subduction volcanic activity controlled by the easternmost prolongation of the Periadriatic Line (PAMIĆ et al., 1995; SACHSENHOFER et al., 2001; FODOR et al., 2008; FODOR, 2019; KOVÁČ et al., 2018). The late early to middle Middle Miocene basin was characterized by extensional tectonics, while compression affected the basin at the Middle/Late Miocene boundary, and from the Pliocene to the Quaternary. The tectonics created the modern structural pattern characterized by uplifted blocks and counterclockwise rotation (TOMLJENOVIĆ \& CSONTOS, 2001; MÁRTON et al., 2002, 2006).

The geological mapping of the HZB established informal Early Miocene lithostratigraphic units that are considered as formations. The Meljani fm. and Golubovec fm. belong to the Egerian, the Macelj fm. belongs to the Eggenburgian and the early Ottnangian while the Bednja fm. is late Eggenburgian to Ottnangian in age. The Early Miocene lithostratigraphic division ends with the Karpatian Crkovec fm. (Fig. 3B) (AVANIĆ, 2012; AVANIĆ et al., 2018a).
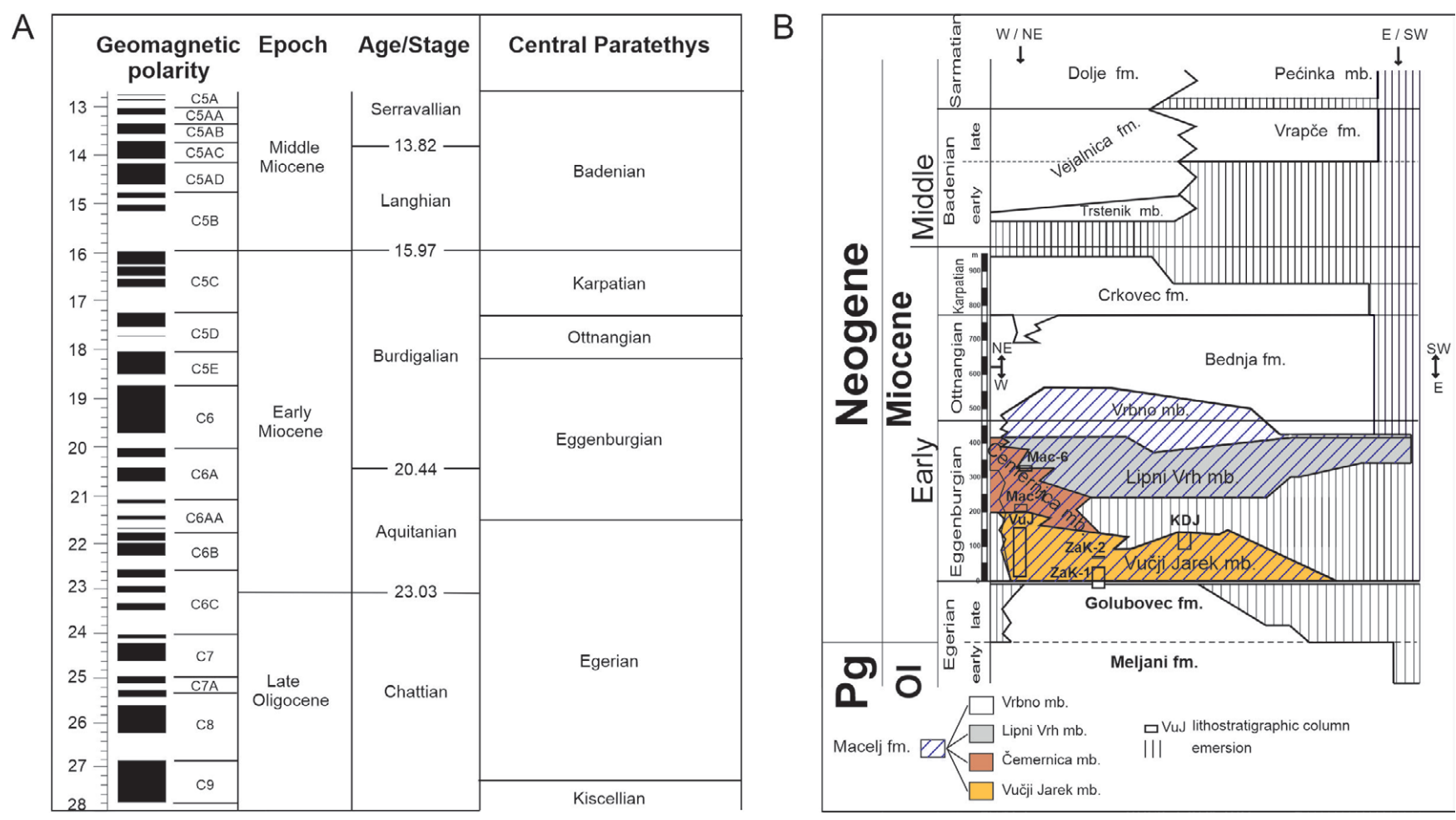

Figure 3. A chronostratigraphy of the Central Paratethys (modified after PILLER et al., 2007). B A simplified lithostratigraphy of the Oligocene, the Early Miocene and the Middle Miocene in the study area (AVANIĆ, 2012). The position of the measured lithostratigraphic columns has been added. 


\section{METHODS}

The fieldwork included detailed, decimetre-scale measuring and sampling of most representative geological sections and individual outcrops of the Vučji Jarek and Čemernica mbs. sediments, and geological mapping of the wider area. Where possible, measurements of the geometry of the depositional units were performed and dimensions of the sedimentary structures were recorded along with facies analysis in the field, in order to interpret depositional mechanisms and environments. Unconformities indicated by abrupt facies changes and their lateral extent were measured in order to define major bounding surfaces. Indications of palaeotransport directions were studied for further discussion on the source of the material. Samples were collected for sedimentological and petrographic analyses with the aim of determining their composition and their provenance.

Four samples of glauconitic material-rich sediments were collected for K-Ar dating to establish their age. Two were taken from the Vučji Jarek mb. glauconitic sandstones (6b/1 and 6b/2), and two from the clayey-silty sands from the Čemernica mb. (Mac-6 and Mac-7) (Fig. 2). Due to glauconite sensitivity to direct sunlight (ODIN, 1982), locations in the shade, fresh and northward oriented outcrops were selected for sampling. In accordance with the higher content of glauconitic material (1.4-3.7 $\mathrm{wt} \%$ ) in the sandstones of the Vučji Jarek mb. compared to the sediments of the Čemernica member (0.2-2.3 wt\%), up to $11 \mathrm{~kg}$ of sample material was taken for the former sandstone unit and up to $20 \mathrm{~kg}$ for the latter (AVANIĆ, 2012). To obtain a pure glauconitic mineral fraction, the samples underwent several cycles of processing. The sandstone samples were crushed to $1 \mathrm{~mm}$ diameter, treated with $10 \% \mathrm{CH}_{3} \mathrm{COOH}$ to remove carbonates, sieved and mechanically scrubbed to remove clay coatings. Glauconitic mineral fractions were separated using the Frantz type magnetic separator and heavy liquid (bromoform) separation. Finally, the purity of the glauconite fractions was improved by hand-picking under the microscope.

X-Ray powder diffraction (XRPD) analysis was performed to test the purity of the glauconite separates, and to determine the maturation stage of glauconite in the different samples. XRPD patterns were recorded using the Philips vertical X-Ray goniometer (type X' Pert) equipped with a Cu-tube $(40 \mathrm{kV}, 40 \mathrm{~mA})$ and graphite monochromator.

IR-spectra were recorded on a Perkin Elmer Spectrum One instrument at the Faculty of Chemistry and Technology in Split using $\mathrm{KBr}$ pressed discs.

The samples were dated at the K-Ar laboratory of the Institute for Nuclear Research (Atomki) in Debrecen (Hungary). Experimental details of the K-Ar method described in BALOGH (1985) were slightly modified for argon measurements. Approximately $0.15 \mathrm{~g}$ of the pure glauconitic samples were wrapped in aluminium foil and a copper sieve. The samples were preheated before radiogenic argon extraction, with the aim of decreasing atmospheric argon contamination. The results of the experiments demonstrate that in the case of evolved to high-evolved glauconites containing at least $6 \%$ potassium, a general bake-out temperature as high as $180^{\circ} \mathrm{C}$ is needed, in order to guarantee complete retention of the radiogenic argon. Consequently, all the glauconitic samples were baked out at the chosen temperature of $180^{\circ} \mathrm{C}$, over $10-12 \mathrm{hrs}$ under a pressure of $10^{-6}$ Torr. Argon was extracted under ultra-high vacuum conditions by radio-frequency induction heating and fusion of rock samples in Mo crucibles. The extracted gas was purified using a Ti sponge and SAES St 707 type getters, to remove chemically active gas contaminants and some liquid nitrogen in a cold trap to remove condensable gases. Argon concentrations were measured by an ${ }^{38} \mathrm{Ar}$ isotope dilution mass spectrometric method, previously calibrated with atmospheric argon and international rock standards. Argon isotope ratios have been normalised to atmospheric argon, accepting 295.5 for the $\left({ }^{40} \mathrm{Ar} /{ }^{36} \mathrm{Ar}\right)$ atm ratio. Potassium was determined by flame photometry with a Na buffer and Li internal standard using a Corning M480 type flame photometer. The K-Ar age of the glauconitic samples is calculated using the decay constants suggested by STEIGER \& JÄGER (1977). Analytical error is given at the $68 \%$ confidence level (1s).

\section{RESULTS AND INTERPRETATION}

\subsection{Facies analysis and petrography}

A $325 \mathrm{~m}$ thick geological sequence was measured at 6 individual locations in the investigated area, which were correlated based on lithological characteristics, fossil content, K-Ar dating results, superposition and geological mapping data (Fig. 4). Within the clastic-carbonate and pyroclastic deposits of the Vučji Jarek Mb. and Čemernica Mb. of the Macelj Fm., four sedimentary facies associations were distinguished and described. The facies associations are mostly of complex composition and are named based on the prevailing facies. They are as follows: Facies of horizontally bedded sands (F1), Facies of horizontally and cross-bedded glauconitic sandstones (F2), Facies of horizontally and cross-bedded pyroclastics (F3), and Facies of structureless clayey-silty sands (F4). Although deposits of facies F1 and F2 are similar, they are distinguished in some details for a better lithostratigraphic correlation for geological mapping, particularly the possibility of defining lower-ranking lithostratigraphic units in the future. An overview of the facies described is given in Table 1.

\subsubsection{VUČJI JAREK MEMBER}

\subsubsection{Facies of horizontally bedded sandstones (F1)}

The Facies of horizontally bedded sandstones (F1) occurs in the upper part of the Zagorska Koprivnica-1 (ZaK-1) and the Zagorska

Table 1. An overview of the lithostratigraphic units of the Macelj formation. The given thicknesses are measured in the field. The spatial distribution of lithostratigraphic units is given in the geological map (Fig. 2).

\begin{tabular}{|c|c|c|c|c|c|}
\hline \multicolumn{6}{|c|}{ MACELJ FORMATION } \\
\hline MEMBER & & FACIES & LITHOLOGICAL CHARACTERISTICS & THICKNESS (m) & ENVIRONMENT \\
\hline Čemernica & F4 & Structureless clayey-silty sands & $\begin{array}{l}\text { Structureless clayey-silty sands, rare horizontal and cross-lamination, } \\
\text { poorly sorted, bioturbation, microfauna }\end{array}$ & $<225$ & Offshore-transition \\
\hline \multirow{3}{*}{ 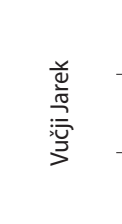 } & F3 & $\begin{array}{l}\text { Horizontally and cross-bedded } \\
\text { pyroclastics }\end{array}$ & $\begin{array}{l}\text { Tuff, pumice, lapilli, large blocks, mostly horizontal bedding, rare } \\
\text { cross-bedding, chaotic pyroclastics with slumps }\end{array}$ & 50 & Shoreface (subtidal) \\
\hline & $\mathrm{F} 2$ & $\begin{array}{l}\text { Horizontally and cross-bedded } \\
\text { glauconitic sandstones }\end{array}$ & $\begin{array}{l}\text { Horizontally and cross-bedded sandstones, horizontal lamination, } \\
\text { fine- to coarse grained, well sorted, mud drapes, molluscs }\end{array}$ & $2-200$ & $\begin{array}{l}\text { Foreshore to shoreface } \\
\text { (subtidal) }\end{array}$ \\
\hline & F1 & Horizontally bedded sandstones & $\begin{array}{l}\text { Horizontally bedded and rare cross-bedded sandstones, wavy and } \\
\text { horizontal lamination, mostly medium grained, moderately sorted }\end{array}$ & 64 & Foreshore to upper shoreface \\
\hline
\end{tabular}



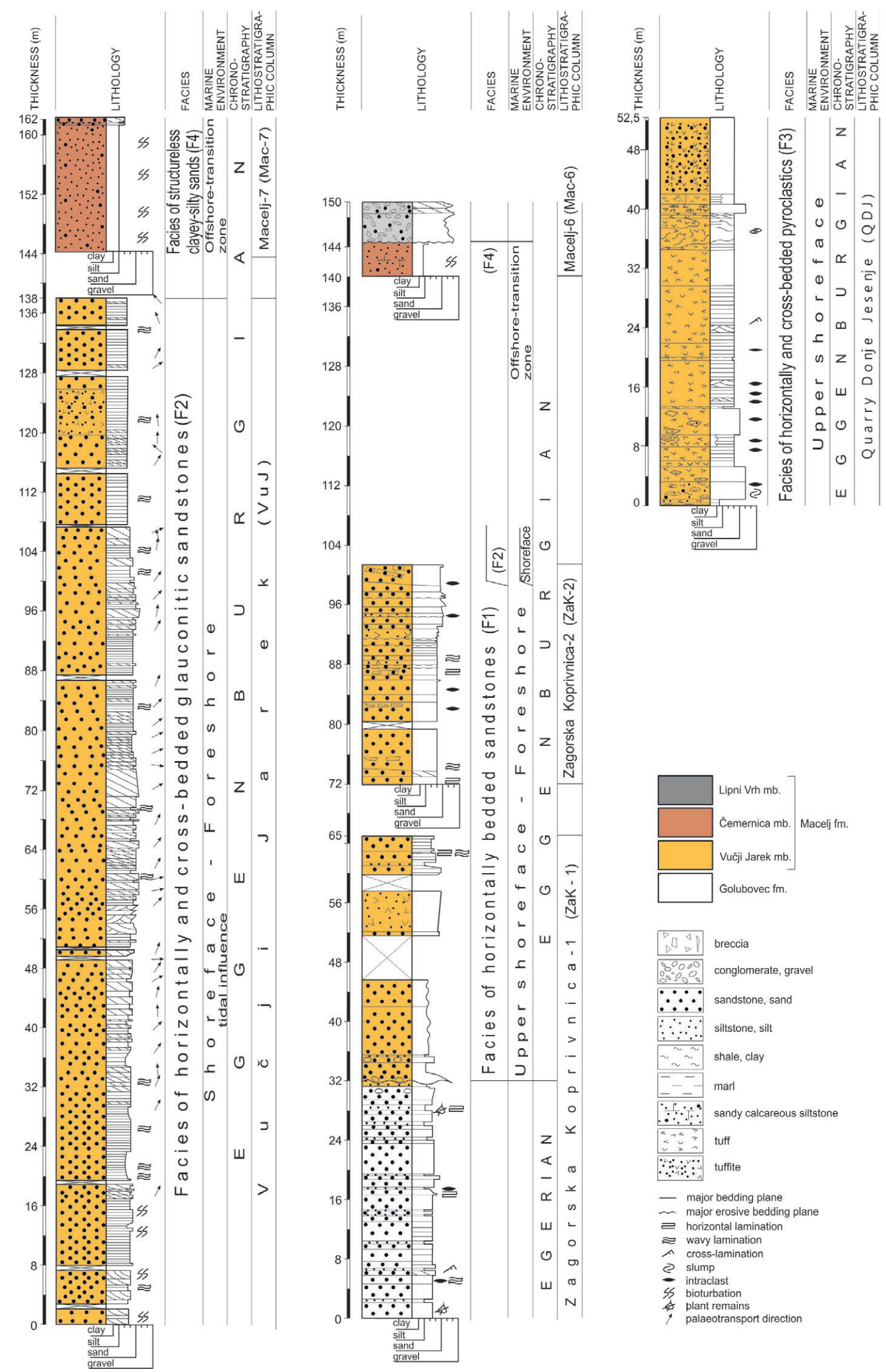

Figure 4. Detailed lithostratigraphic columns and correlation. See Fig. 2 for the locations of the lithostratigraphic columns, and Fig. 3B for their chronostratigraphic position.

Koprivnica-2 (ZaK-2) sections (Fig. 4). These deposits overlie Egerian marine to brackish deposits of the Golubovec fm. (Fig. $5 \mathrm{~A}$ ), and are overlain by the Facies of horizontally and cross-bedded glauconitic sandstones (F2). Laterally, they are correlatives of the lower part of the F2 facies. The contacts between the two facies were not visible at the outcrop. The maximum thickness of the deposits is about $54 \mathrm{~m}$ (Fig. 4). The F1 is represented mostly by more or less lithified horizontally bedded sandstones, with bed thicknesses between 1 and $10 \mathrm{~cm}$. Bedding planes are sharp. Some beds show irregular wavy lamination that exhibits a lateral 


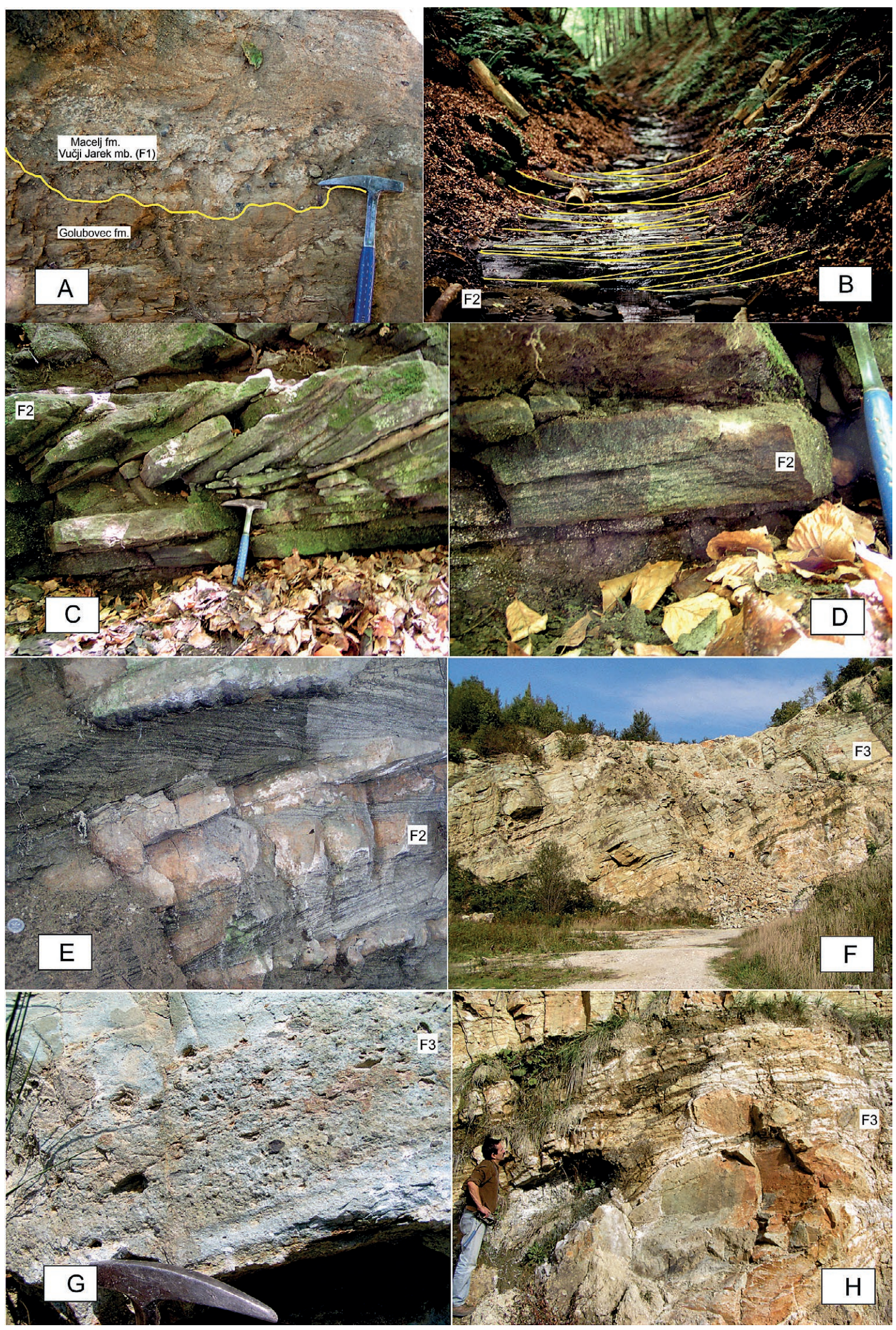

Figure 5. Deposits of the Vučji Jarek mb. A The yellow line shows the erosional and transgressive contact between horizontally bedded sandstones (F1) of the Vučji Jarek mb. (above) and sands with silts of the Golubovec fm. (below) in the Zak-1 section (Figs. 2 and 4) B Cross-bedding (marked with yellow line) in the Facies of horizontally and cross-bedded glauconitic sandstones (F2) in the VuJ section (Figs. 2 and 4) C The contact between tangential cross-bedded sandstone (above the hammer) and horizontally laminated sandstones (hammer level). Detail of the Facies of horizontally and cross-bedded glauconitic sandstones (F2) at the level of $44^{\text {th }} \mathrm{m}$ of the Vučji Jarek section (Fig. 4). D Detail of the horizontal lamination in the F2 facies (hammer level on Fig. 5c). E Wide and flat troughs in a section nearly perpendicular to the transport direction in glauconitic sandstones of the F2 facies at the locality of Osredečki (Fig. 2). F The quarry in the pyroclastics in the Donje Jesenje (Figs 2 and 4). Well developed bedding is visible. G In the central part of the photo, dark grey clastics of devitrified pumice from the F3 facies is observed as an indication of synsedimentary explosive volcanic activity in the Donje Jesenje Quarry (Figs. 2 and 4.) H Chaotic pyroclastics with large clasts of F3 facies indicating the proximity of the volcano in the upper part of the Donje Jesenje Quarry (Fig. 4). 


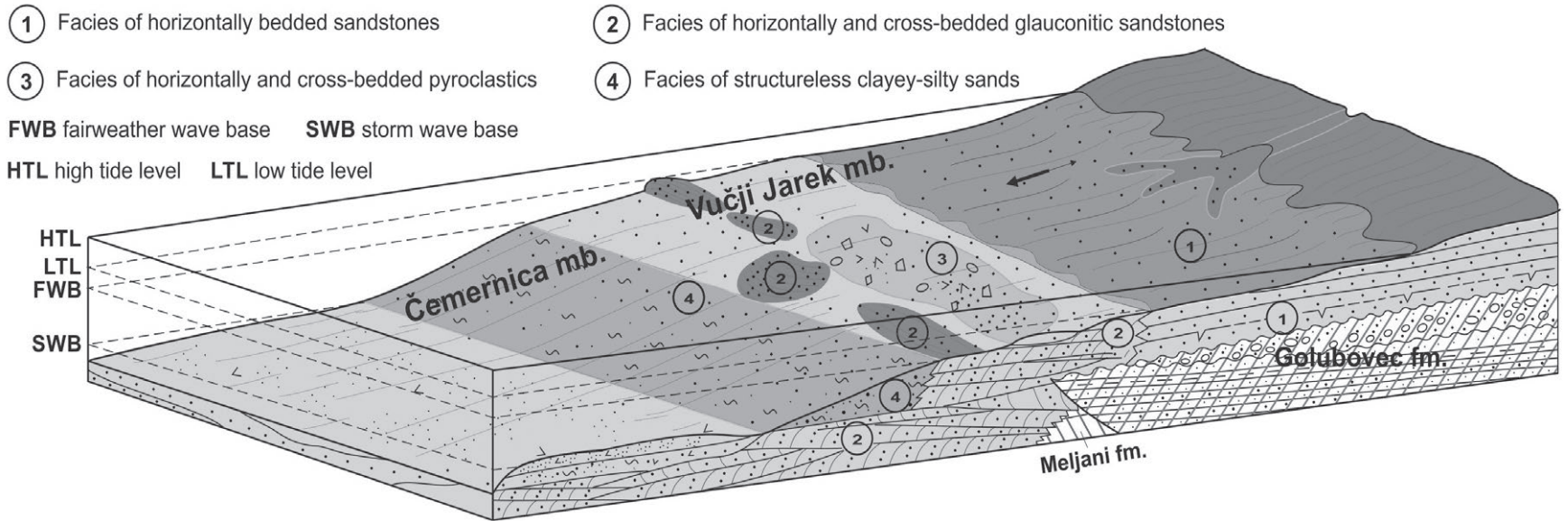

Figure 6. Sedimentation model of the Vučji Jarek mb. and the Čemernica mb.

transition to horizontal lamination. Cross-bedding rarely occurs. The sandstones are mostly medium-grained and moderately sorted. In the medium-grained sandstone, silt intraclasts occur. In the upper part of the ZaK-1 section (Fig. 4), fine-grained sandstones overlie medium-grained sandstones, in places forming small-scale fining upwards cycles. In the lower part, the cycles are composed of coarse-grained sandstone, which includes limonitic silty sand intraclasts with an erosional lower bedding plane. Sandstones of the F1 facies consist of quartz, lithic particles mostly represented by tuff and volcanic glass, feldspars and glauconite. Staurolite, tourmaline, garnet and zircon predominate in the heavy mineral fraction ${ }^{1}$.

Varying grain-sizes in the sandstones indicate deposition by fluctuating strong and weak currents while shallow marine molluscs suggest a marine depositional environment (AVANIĆ, 2012). In the marine depositional environment, such deposits were probably accumulated by traction currents (ALLEN, 1984; HOWARD \& REINECK, 1981) in the foreshore and upper shoreface as indicated by horizontal and wavy lamination and crossbedding (Fig. 6) (CLIFTON et al., 1971; LEITHOLD \& BOURGEOIS, 1984; CHEEL, 1990; summarized in DASHTGARD et al., 2012). Small-scale fining upwards cycles can be a result of relative sea level rise in the nearshore. The mineralogical composition of sandstones indicates a permanent supply of terrestrial material while the $64 \mathrm{~m}$ thickness of F1 suggests a relatively longlasting shallow water environment.

\subsubsection{Facies of horizontally and cross-bedded glauconitic sandstones (F2)}

The Facies of horizontally and cross-bedded glauconitic sandstones (F2) was measured on the Vučji Jarek section (Figs. 4 and 5B-E). Deposits of F2 are overlain by deposits of the Facies of structureless clayey-silty sands (F4) (Fig. 4). The contact between the facies is not exposed. The thickness of the F2 deposits reaches $138 \mathrm{~m}$ (Fig. 4). The horizontally bedded sandstones (Fig. 5D) predominate over the cross-bedded sandstones (Figs. 4 and 5B). They are generally thicker (range $1-20 \mathrm{~cm}$ ) than similar deposits of the F1 facies. The cross-bedding shows the planar, tangential (Fig. 5C) and trough (Fig. 5B) types. The planar and tangential cross-bedded sets are 0.1 to $3.5 \mathrm{~m}$ thick, while the trough cross-

\footnotetext{
1 ŠIMUNIĆ, AL. (1990): Sedimentno-petrografske analize. Geološka karta 1:50.000, Potprojekt-4.- Fond struč. dok., Hrv. geol. instituta, Zagreb, Zagreb.
}

bedded sets range from 0.5 to $1.5 \mathrm{~m}$. Individual troughs within sets are up to $12 \mathrm{~m}$ wide. Occasionally mud drapes up to a few $\mathrm{mm}$ thick can occur. Sets are separated by horizontally bedded and laminated sandstones. Sandstones are fine- to coarse-grained and well sorted. Their colour is greyish to greenish due to the glauconite which is more concentrated in some laminae. The grains are pellet- and "kidney-"shaped with a cryptocrystalline to microcrystalline and flaky structure, determined as the poorly crystalized dioctahedral mica illite, celadonite or glauconite ${ }^{2}$. Except for the glauconite grains, quartz, lithic particles and feldspars prevail in the sandstone composition, while chlorite, muscovite and biotite rarely occur (ŠIMUNIĆ, AL. et al., 1988). The feldspars are represented by microcline, oligoclase and andesine. The lithic particles are represented by metamorphic rock fragments (quartzite, and quartz, mica, sericite and chlorite schists), altered volcanics, felsic intrusives (granite and pegmatite), tuffs, cherts, carbonates and shales (ŠIMUNIĆ, AL. et al., 1990). The carbonate particles are composed of dolomite and skeletal fragments of marine organisms. Translucent minerals prevail within the heavy mineral fraction, represented by tourmaline, zircon, apatite, staurolite, rutile, epidote and amphibole. The sandstone is cemented by a mixture of quartz, dolomite and calcite with rare amounts of matrix (ŠIMUNIĆ, AL. et al., 1990). The sandstones are determined as glauconitic lithic arenites, graywackes and glauconitic graywackes (ŠIMUNIĆ, AN. et al., 1995).

A mollusc assemblage was observed mostly composed of pectenid remains. Several species were recognized including Aequipecten? northamptoni oblita MICHELOTTI, Aequipecten macrotis SOWERBY, Aequipecten? cf. darnoensis CSEPREGHYMÈZNERICS, Gigantopecten ex gr. holgeri (GEINITZ), Flabellipecten ex gr. burdigalensis (LAMARCK), Pecten sp., P. psudobeudanti DEPRÉT \& ROMAN, Gastrana fragilis gracilis SCHAFFER $^{3,4}$. The marine macrofossil association indicates the Eggenburgian age (sensu MANDIC \& STEININGER, 2003).

${ }^{2}$ PROHIĆ, E. (1988): Rezultati rentgenskih analiza. Geološka karta 1:50.000, Potprojekt 4.- Fond struč. dokument. IGI, Zagreb, 193/88.

3 ŠIKIĆ, K. (1991): Makropaleontološke analize.- Fond struč. dok., Hrv. geol. instituta, Zagreb, Zagreb.

4 ŠIKIĆ, K. (2004): Makropaleontološke analize uzoraka na potprojektu "Klastično-karbonatni kompleks neogena Hrvatskog zagorja”. Projekt Geološka karta RH 1:50.000.- Fond struč. dok., Hrv. geol. instituta, Zagreb, Zagreb. 
Measurements of the planar cross-beds foreset orientation at the Vučji Jarek section indicate a palaeotransport direction towards $27^{\circ}$, i.e. towards the north-northeast (Fig. 4). The palaeotransport direction was also measured on the cross-bedded glauconitic sandstones exposed at outcrops and during geological mapping (Fig. 2). All measurements indicate a general northwest to northeast direction, with an average value of $352^{\circ}$, i.e. basinwards according to Central Paratethys palaeogeographic reconstructions (Fig. 1B) (POPOV et al., 2004; HARZHAUSER \& PILLER, 2007; KOVÁČ et al., 2017).

The fossil association documents a shallow marine environment. The horizontal lamination suggests deposition in the upper flow regime while the cross-lamination indicates deposition by traction (ALLEN, 1984; HOWARD \& REINECK, 1981) probably in the shoreface surf to the foreshore swash zone (Fig. 6) (CLIFTON et al., 1971; LEITHOLD \& BOURGEOIS, 1984; SWIFT et al., 1987). The planar, tangential and trough cross-bedding suggest deposition probably by 2D and 3D subaqueous bedforms. The $1.5 \mathrm{~m}$ thick troughs indicate migration of large dunes by strong currents (ASHLEY, 1990). The palaeotransport generally towards to the north, i.e. basinwards, and mud drapes indicate deposition by ebb currents suggesting of a shoreface dominated by tides, where the bedforms comprised sandwaves (ALLEN, 1980: VISSER, 1980; DALRYMPLE, 1992; NIO \& YANG, 1991; DESJARDINS et al., 2012; LONGHITANO et al., 2014), in accordance with earlier interpretations (ŠIMUNIĆ, AL. et al., 1988, 1990; AVANIĆ et al., 2005; AVANIĆ, 2012). Similar to the F1 facies, the composition and the thickness of F2 indicate a strong terrestrial influence and nearshore deposition with a tidal influence during a relatively long period.

\subsubsection{Facies of horizontally and cross-bedded pyroclastics (F3)}

The Facies of horizontally and cross-bedded pyroclastics (F3) was studied in detail in the Donje Jesenje quarry (Figs. 4 and 5F-H). Geological mapping indicated that deposits of the F3 facies represent a lense within deposits of the F2 facies and are laterally correlative with the upper part of the F2. The contact with overlying deposits is not visible. These pyroclastic deposits form a $52.5 \mathrm{~m}$ thick succession (Fig. 4). They are mostly horizontally bedded, and demonstrate a bed thickness that usually varies between 1 and $30 \mathrm{~cm}$. Occasionally, amalgamated beds were dis- covered, reaching a thickness up to $5 \mathrm{~m}$. Trough cross-bedded pyroclastics of sandy grain-size were recognized in a few beds.

In the F3 facies, tuffs prevail, exhibiting vertical alternation of vitric, vitric-crystal, crystal and crystal-lithic types (GOLUB \& BRAJDIĆ, 1969; ŠIMUNIĆ, AL. et al., 1988). Pumice characterized by voids that are irregularly dispersed or parallel to the bedding plane is intercalated within the pyroclastics (Fig. 5G). The voids are either empty or are infilled with clayish material produced by devitrification of volcanic glass (TIBLJAŠ \& ŠĆAVNIČAR, 2007). Various clay minerals, zeolites (clinoptilolite, mordenite and analcime), feldspars and $\mathrm{SiO}_{2}$ phases were determined as the result of devitrification processes (TIBLJAS̆, 1996; TIBLJAŠ \& ŠĆAVNIČAR, 1988, 2007). In the vitric and crystal tuffs, volcanic glass shards, and crystal grains of feldspar (andesine) and biotite predominate, while amphiboles and quartz are present in smaller amounts. In varieties where biotite is more abundant within the tuff matrix, besides glass shards, microcrystalline quartz, zeolites, chlorite, magnetite and feldspar, microlites were determined (ŠIMUNIĆ, AL. et al., 1990). The lithic tuffs are mostly composed of tuff and effusive rock particles, followed by mineral porphyroclasts and glass shards. Vitric tuffs contain a low alkali and iron content, while the crystal tuffs contain a significantly higher amount of alkalis, aluminium and iron (GOLUB \& BRAJDIĆ, 1969). Based on the $\mathrm{SiO}_{2}$ content (65$70 \%$ ), the tuffs were determined as dacite-andesite types (GOLUB \& BRAJDIĆ, 1969).

In the lower and the upper part of the succession, chaotic pyroclastics with slumps occur (Figs. 4 and $5 \mathrm{H}$ ). They consist of tuffs with dispersed lapilli fragments composed of volcanic glass, and lithic and crystal particles. The lithoclasts are mostly andesite or tuff clasts. Rarely rounded tuff blocks up to $5 \mathrm{~m}$ in diameter occur. The uppermost part of the succession is characterized by tuffs that are strongly affected by recent weathering processes that resulted in their alteration into a sandy material.

Deposition of the pyroclastics probably took place in an aquatic depositional environment as indicated by pumice with voids formed parallel to bedding planes that reflects the rapid cooling of volcanic ash in water, and by relatively quick settling on the bottom (Fig. 7) (WHITHAM \& SPARKS, 1986; McPHIE et al., 1993; CAS \& WRIGHT, 1995). The association with de-

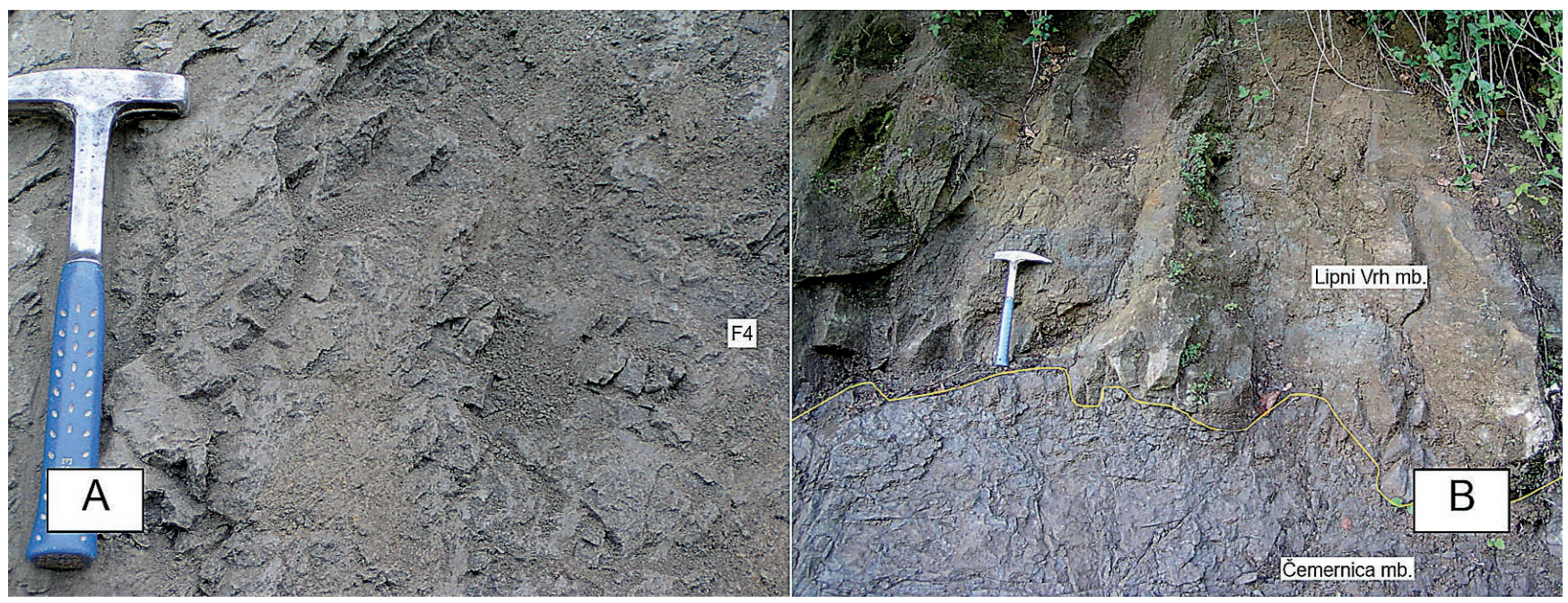

Figure 7. Facies of structureless clayey-silty sands (F4) of the Čemernica mb. at the Čemernica section (Figs. 2 and 4). A Deposits are composed of a poorly sorted mixture of sand-, silt- and clay-sized material. Bedding is not developed probably due to bioturbation. B Erosional boundary (yellow line) between structureless clayey-silty sands (F4) of the Čemernica mb. (below) and the weathered conglomerates and sandstones of the Lipni Vrh mb. (above) at the Macelj-6 section (Figs. 2 and 4). 
posits of facies F2 suggests shallow marine deposition. The material was probably reworked by strong upper shoreface traction currents that formed horizontal beds (Fig. 7). The shallow water deposition is supported by cross-bedded pyroclastics. They suggest subaqueous dune migration probably by tides on the shoreface, similar to cross-bedded sandstones of the F2 facies (CLIFTON et al., 1971; LEITHOLD \& BOURGEOIS, 1984; ASHLEY, 1990; NIO \& YANG, 1991). The absence of mixing with the shoreface siliciclastic material is probably a consequence of the proximity of the volcano.

Chaotic pyroclastics in the lower and upper part of the succession are interpreted as a result of slumping generated by seismic shocks that caused liquefaction and destabilization of the pyroclastic material (sensu CAS \& WRIGHT, 1995). The significant thickness of the deposits implies relatively long-lasting explosive volcanic activity. This activity was characterized by its variable intensity. Intense volcanism produced the crystalline tuff and a high accumulation of pumice, while quieter volcanism resulted in vitric tuff and low accumulation of pumice (ŠIMUNIĆ, AL. et al., 1988; McPHIE et al., 1993). The lateral correlation of the pyroclastics with deposits of the F2 facies indicates the Eggenburgian age of the explosive volcanic activity.

\subsection{2. ČEMERNICA MEMBER}

\subsubsection{Facies of structureless clayey-silty sands (F4)}

The Facies of structureless clayey-silty sands (F4) was studied at the Macelj-6 and Macelj-7 localities (Fig. 2). The deposits of F4 overlie the F2 facies but the direct contact is not exposed in the studied area. The sands are erosively overlain by conglomerates of the Lipni Vrh mb. (Fig. 7B) that belong to the upper part of the Macelj fm. (AVANIĆ, 2012). The measured thickness of the F4 deposits is $18 \mathrm{~m}$ and consists of a $17 \mathrm{~m}$ thick sandy unit overlain by a $1 \mathrm{~m}$ thick horizontally and planar cross-bedded sandstone unit. The sandy unit is characterized by intense burrowing that produced the structureless poorly sorted mixture of sand-, siltand clay-sized particles (Fig. 7A). Ichnofossils and marl intraclasts are abundant in the unit. Rare horizontal lamination and cross-lamination that occur in the top bed indicate primary structures. The composition of the light mineral fraction is characterized by the predominance of quartz over lithoclasts and K-feldspars, while glauconite grains rarely occur ${ }^{5,6}$ (ŠIMUNIĆ, AN. et al., 1995). In the heavy minerals fraction translucent grains prevail, among which garnet is the most abundant, while tourmaline, staurolite and rutile are less common. The $\mathrm{CaCO}_{3}$ content is $12.3-17 \mathrm{wt} \%$. Sands are more lithified in places than others, hence their mineral composition is more similar to the F2 deposits. They are composed of quartz of volcanic origin, feldspars, chloritized biotite, volcanic glass shards, tuff and volcanic rocks, with a lower glauconitic content compared to the F2 facies. This is also evident in their colour which is more yellowish to greenish or greyish to yellowish (ŠIMUNIĆ, AN. et al., 1995; ALJINOVIĆ et al., 2003).

In the sediments of facies F4, the following microfaunal assemblage was determined: Semivulvulina pectinata (REUSS), Spirorutilus carinatus (D'ORBIGNY), Elphidium subtypicum

\footnotetext{
${ }^{5}$ GRIZELJ, A. (2004a): Sedimentno-petrografske analize uzoraka s geološkog kartiranja (2002). Projekt Geološka karta RH 1:50.000.- Fond struč. dok., Hrv. geol. instituta, Zagreb, Zagreb.

${ }^{6}$ GRIZELJ, A. (2004b): Sedimentno-petrografske analize uzoraka s prospekcijskih točaka (2003). Projekt Geološka karta RH 1:50.000.- Fond struč. dok., Hrv. geol. instituta, Zagreb, Zagreb.
}

PAPP, E. crispum (LINNE), E. ortenburgense (EGGER), Cibicidoides sp., C. budayi CICHA \& ZAPLETALOVA, Heterolepa praecincta (KARRER) and H. dutemplei (D'ORB.) ${ }^{7}$. Along with the mentioned foraminifera, in a further study Lenticulina inornata (D'ORB.), L. cultrata (MONTFORT), Bolivina fastigia CUSHMAN, Fontbotia wuellerstorfi (SCHWAGER) and Pullenia bulloides (D'ORB.) were determined. A fossil shell mold of Anadara sp. was also observed ${ }^{8}$. The Cibicidoides-Heterolepa group is usually related to oxic conditions, Spirorutilus carinatus implies an increased nutrient input, while the less abundant Lenticulina sp. and Bolivina sp. indicate suboxic conditions at the bottom of the sea. Such an assemblage originates from the offshore area (RÖGL \& SPEZZAFERRI, 2003; SPEZZAFERRI et al., 2004). Palynological analyses ${ }^{9}$ yielded a small number of spores including ?Cicatricosisporite sp., as well as the dinocysts ?Homotryblium sp. and Operculodinium sp. Associations that includes Elphidium ortenburgense (EGGER) indicates the Central Paratethys Eggenburgian age of the deposits of the F4 facies (PILLER et al., 2007; PIPPÈRR \& REICHENBACHER, 2009), although some recent studies indicate the possibillity of an Ottnangian (GRUNERT et al., 2012; PIPPERR et al., 2018) or Karpatian age (HARZHAUSER et al., 2017).

Palaeoecological characteristics of the faunal association indicate a marine environment where prevailing fine-grained deposits and common bioturbation suggest deposition from suspension and low energy conditions, probably below the fair weather wave base. Cross-lamination in the uppermost sand indicates ripple migration, i.e. deposition by traction (ALLEN, 1968). Such currents might be generated by a storm that affected the coast causing reworking and redeposition of the beach material below the fair-weather wave-base, in the offshore-transition zone (Fig. 7) (KUMAR \& SANDERS, 1976; BOURGEOIS, 1980; BOURGEOIS \& LEITHOLD, 1984). The clayey-silty sand that shows intensive bioturbation might reflect organic activity during fair weather. The prevailing siliciclastic material suggests a strong terrestrial influence on deposition.

\subsection{K-Ar dating results and chronology of the Macelj formation}

In order to reconstruct the evolution of the sedimentary history of the study area, and for better correlation of studied sediments with similar Early Miocene deposits in the Central Paratethys, four representative glauconite-rich samples were selected for dating: Mac-6 and Mac-7 (Čemernica mb.) and 6b/1 and 6b/2 (Vučji Jarek mb.) (Fig. 2). The analytical data and the dating results are summarised in Tables 2 and 3. The chronostratigraphic timescale of Central Paratethys compiled by PILLER et al. (2007) was used for the correlation and interpretation of the obtained K-Ar ages.

To test whether the glauconitic separates from the representative samples from the Čemernica and Vučji Jarek mbs. are suitable for dating they were analysed in more detail. XRPD analyses

\footnotetext{
7 ŠIKIĆ, L. (1988): Izvještaj o mikropaleontološkim analizama s područja sjeverozapadne Hrvatske. Geološka karta SFRJ 1:50 000, Potprojekt 4.- Fond struč. dok., Hrv. geol. instituta, Zagreb, Zagreb.
}

8 ŠIKIĆ, K., (2004): Makropaleontološke analize uzoraka na potprojektu "Klastično-karbonatni kompleks neogena Hrvatskog zagorja”. Projekt Geološka karta RH 1:50.000.- Fond struč. dok., Hrv. geol. instituta, Zagreb, Zagreb.

${ }^{9}$ BAKRAČ, K. (2004): Palinološke analize za zadatak: Klastično-karbonatni kompleks neogena Hrvatskog zagorja, Projekt Geološka karta RH 1:50.000.Fond struč. dok., Hrv. geol. instituta, Zagreb, Zagreb. 
Table 2. $\mathrm{K}_{2} \mathrm{O}$ content, determined by flame photometry, $\mathrm{d}_{001}$ and expandable layers \%, determined by XRPD, in glauconitic separates from the Macelj fm.

\begin{tabular}{|c|c|c|c|c|c|c|}
\hline Formation & Member & Column & Sample & $\mathrm{K}_{2} \mathrm{O}(\%)$ & $\mathrm{d}_{001}(\AA ̊)$ & Expandable layers (\%) \\
\hline \multirow{4}{*}{ Macelj (Mac) } & \multirow{2}{*}{ Vučji Jarek (VuJ) } & \multirow{2}{*}{ Vučji Jarek (VuJ) } & $6 b / 1$ & 7.75 & 10.26 & 6 \\
\hline & & & $6 b / 2$ & 8.03 & 10.18 & 5 \\
\hline & \multirow{2}{*}{ Čemernica (Čem) } & Macelj-6 & Mac-6 & 6.24 & 10.65 & 16 \\
\hline & & Macelj-7 & Mac-7 & 5.58 & 10.94 & 23 \\
\hline
\end{tabular}

Table 3. $\mathrm{K}$ and ${ }^{40} \mathrm{Ar}$ content and the corresponding $\mathrm{K}$-Ar isotopic age of glauconitic materials of the Macelj fm.

\begin{tabular}{ccccc}
\hline Sample & $\mathrm{K}(\%)$ & ${ }^{40} \mathrm{Ar} \mathrm{rad}(\%)$ & $\begin{array}{c}{ }^{40} \mathrm{Ar} \mathrm{rad}{ }^{*} 10^{-6} \\
(\mathrm{cc} / \mathrm{STP} / \mathrm{g})\end{array}$ & $\mathrm{K}-\operatorname{Ar}(\mathrm{Ma})$ \\
\hline $6 \mathrm{~b} / 1$ & 6.44 & 44.3 & 5.696 & $22.62 \pm 0.86$ \\
\hline $6 \mathrm{~b} / 2$ & 6.67 & 61.4 & 5.005 & $19.21 \pm 0.64$ \\
\hline Mac-6 & 5.18 & 55.1 & 4.535 & $22.38 \pm 0.77$ \\
\hline Mac-7 & 4.63 & 51.2 & 4.189 & $23.14 \pm 0.82$ \\
\hline
\end{tabular}

showed that no impurities were present in the separated glauconitic material and that excellent separates were obtained, providing reliable material for K-Ar dating. Furthermore, the recorded patterns show that the investigated glauconitic material differ significantly (Fig. 8). The diffraction pattern obtained from sample Mac6 representing the Čemernica mb. has broader diffraction maxima, best seen on the 001 peak, indicating a higher expandable layer content. Observed d(001) values, $10.65 \AA$ for the Mac6 sample and $10.26 \AA$ for the $6 \mathrm{~b} / 1$ sample, are in accordance with this statement and indicate the presence of 16 and $6 \%$ of expandable layers, respectively (Tab. 2). Lower intensities of poorly resolved (in contrast to $6 \mathrm{~b} / 1$ sample) $11 \overline{2}$ and 112 peaks also indicate that glauconite in the Mac 6 sample is less evolved. The observed $\mathrm{d}_{(060)}$ of $1.511 \AA$ for the Mac6 sample, compared to the $1.516 \AA$ peak from the $6 b / 1$ sample representing the Vučji Jarek mb., possibly indicates a higher Al content in the octahedral sheet of the former sample (RADOSLOVICH, 1962). This is in accordance with observed IR spectra. Even though the IR spectra of both samples are characterized by poorly resolved broadened bends, they differ in the appearance of the $\mathrm{OH}$-stretching region.
Čemernica mb. samples have more pronounced bands at 3603 and $3625 \mathrm{~cm}^{-1}$, which can be ascribed to Al-Mg and Al-Al cationic environments of the $\mathrm{OH}$ groups, respectively (BESSON \& DRITS, 1997), in addition to bands at $3557\left(\mathrm{Mg}-\mathrm{Fe}^{3+}\right.$ and $\left.\mathrm{Al}-\mathrm{Fe}^{2+}\right)$ and $3530 \mathrm{~cm}^{-1}\left(\mathrm{Fe}^{3+}-\mathrm{Fe}^{3+}\right)$ which are practically the only visible ones in the Vučji Jarek sample.

Such XRPD results are in accordance with the $\mathrm{K}_{2} \mathrm{O}$ content in the analysed samples obtained by flame photometry (Tab. 2). The glauconitic materials from the Vučji Jarek mb. have a higher $\mathrm{K}_{2} \mathrm{O}$ content $(7.75-8.03 \%)$ compared to those from the Čemernica $\mathrm{mb}$. (5.58-6.24\%). Based on the $\mathrm{K}_{2} \mathrm{O}$ content (Tab. 2) glauconites Mac-6 and Mac-7 (Čemernica mb.) can be classified as slightly evolved to evolved glauconite, while samples $6 \mathrm{~b} / 1$ and $6 \mathrm{~b} / 2$ (Vučji Jarek mb.) can be classified as evolved to highly-evolved glauconite (ODIN \& DODSON, 1982; ODIN, 1982). According to the relation given by VELDE \& ODIN (1975) these values, in accordance with XRD data (Tab. 2), indicate that the content of the expandable layers in glauconitic materials from Vučji Jarek and Čemernica samples is approximately 5-6 and 19-25\%, respectively.

It is known that the basis for the formation of authigenic glauconite on the sea floor is the initial substrate, which consists of various components including quartz, silica, mica, feldspars, clay minerals, phosphates, aragonite, calcite, pyroclastic material and others (ODIN \& DODSON, 1982). The exchange of these components takes place within the substrate, which leads to the growth of glauconitic material in the pores. In the samples studied, glauconitic material is present as a psudomatrix between quartz grains therefore it can be presumed that it is formed in situ (Fig. 9). In the present study, it was not possible to determine

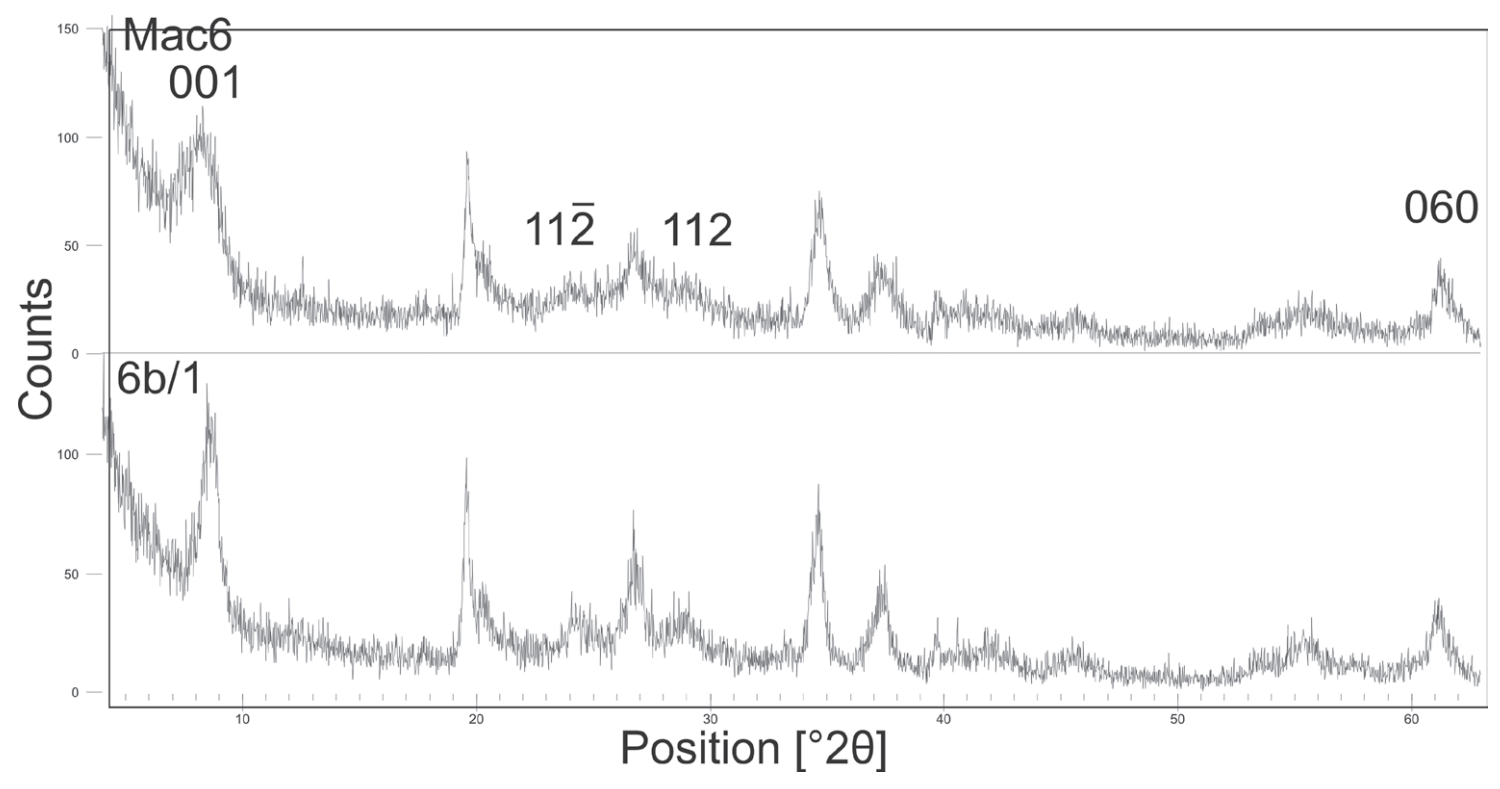

Figure 8. XRPD patterns of glauconitic materials from samples $6 \mathrm{~b} / 1$ and Mac- 6 belonging to the Vučji Jarek and Čemernica members respectively. $001,11 \overline{2}, 112$ and 060 peaks are indexed (Cu Ka radiation). See text for the explanation. 


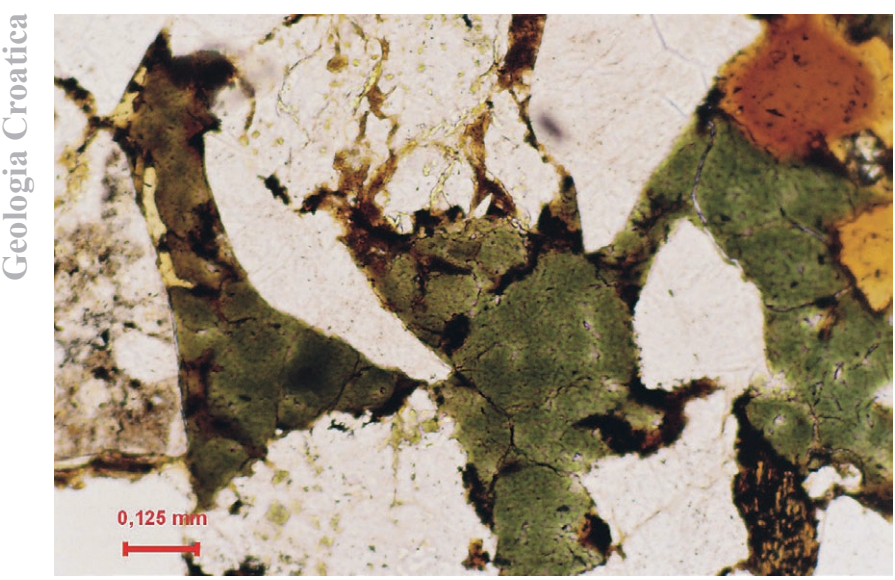

Figure 9. A photomicrograph of glauconitic sandstone of the Vučji Jarek member, locality $6 \mathrm{~b}$ (plane polarized light). Glauconite (green) is present between the quartz grains (white) in the form of a pseudomatrix.

which type of initial substrate was transformed into glauconitic material. However, according to ALJINOVIĆ et al. (2003), glauconitic material in the intergranular pores of the oldest sandstones in the Macelj fm. resulted from the transformation of the primary matrix, which was related to volcanic material deposited directly from the air into the basin. For other sandstones, they suggest erosion of volcanic rocks located in the source area i.e. the volcanic material can be older than the host sediments. TADEJ et al. (1997) in their study of glauconitic material from the Macelj sandstones observed that there are differences, not only between glauconitic material from three different locations (not the same as in the present study) but also between glauconitic material from the same sandstone sample. They also noticed that in the same sample glauconitic material occurs in two basic forms; as detrital grains and as the matrix material.

An analytical error value is given to the apparent age of each specific sample (Tab. 3). This analytical error may be used for comparison of the significance of the individual age results in this study, but has hardly any statistical value. It should be noted that the precision of the analysis is limited by the potassium determinations, which were made on a split of the dated sample by flame photometry and is dependent of the inhomogeneity of the powdered sample. As a consequence, the "sampling error" can be more significant than the analytical error. Table 3 shows that there is a considerable spread in age values, ranging from $19.2 \pm 0.64$ Ma to $23.1 \pm 0.82 \mathrm{Ma}$. However, the ages seem to reflect two different events; an "older episode" (23.1-22.4 Ma) and a "younger one" (at about 19.2 Ma).

The ages of $22.4 \pm 0.77 \mathrm{Ma}, 23.1 \pm 0.82 \mathrm{Ma}$ and $22.6 \pm 0.86 \mathrm{Ma}$ obtained from samples Mac-6, Mac-7 and 6b/1, respectively, are in excellent agreement and consistent within errors (Table 3). Such agreeable data are especially significant since the dated samples come from a well-defined stratigraphic position. However, the potassium analyses for these samples exhibit a highly different concentration of potassium. This could be due to the inhomogeneity of the samples. In that case, the measured ages are probably overestimated and do not indicate the timing of the deposition, it could rather imply the recycling of detrital glauconite from older sedimentary rocks, without completely resetting and obtaining an equilibrium with the depositional environment. Such discordant K-Ar ages are believed to result from the incorporation of varying amounts of "inherited" ${ }^{40} \mathrm{Ar}$ from older sedimentary units. In the case of Čemernica samples, the much lower potassium content is the result of the fact that glauconitic material contains a higher content of expandable layers (it is only slightly-evolved to evolved). According to ODIN \& FULLAGHAR (1988), glauconitic materials that are not highly evolved are usually characterized by the inheritance of radiogenic isotope and show a higher age, so the ages obtained on these samples should be taken with caution. Furthermore, it should also be noted that the mobility of potassium in the altered glauconites often results in K-Ar data that are too old i.e. overestimated (the obtained analytical age is older than the real geological age). Finally, the youngest obtained age of $19.21 \pm 0.64 \mathrm{Ma}$ (sample $6 \mathrm{~b} / 2$ ) can be regarded as the geological age of the sediment, because it is also supported by stratigraphic, mineralogical (glauconite with the lowest expandable layer content present as a pseudomatrix), geochemical (the highest potassium content i.e. the most evolved material among the investigated) and chronological arguments. In the absence of other suitable geochronometers in the case of such pure glauconite and despite the analytical difficulties, the obtained K-Ar age can be reliably used for correlation with similar deposits. So, the K-Ar dating of glauconitic deposits of the Vučji Jarek mb. is in accordance with biostratigraphic analyses that indicate their Eggenburgian age.

\section{DISCUSSION}

\subsection{Vertical succession and sea level changes}

Marine deposits of the Macelj fm. represent the middle part of the Lower Miocene sequence in the HZB as indicated by stratigraphic dating and geological mapping. They are underlain by marine to brackish deposits of the Golubovec fm., and are overlain by marine offshore to nearshore deposits of the Bednja fm. and the Crkovec fm. (Fig. 3B).

The Macelj fm., that consists of the Vučji Jarek mb., Čemernica mb., Lipni Vrh mb. and Vrbno mb. (Fig. 3B), indicates dynamic deposition in a changeable marine nearshore environment. The Vučji Jarek mb., which is composed mostly of sandstones and pyroclastics, reflects beach to shoreface deposition that was affected by tides. Deposits of the Čemernica mb. that is composed mostly of clayey-silty sands, were interpreted as an offshore-transition zone. The Lipni Vrh mb. that consists of deltaic conglomerates and sandstones (ŠIMUNIĆ, AN. et al., 1995), interfingers with the Čemernica mb., and transgressively overlies older rocks.

In the vertical succession, the Vučji Jarek mb. belongs to the lower part of the Eggenburgian Macelj fm. The contact with the older, Egerian Golubovec fm., is erosional and transgressive. This implies a relatively short emersion at the end of the Egerian that was followed by a transgression and subsequent deposition in a shallow sea in the early Eggenburgian. The return to a new marine environment was followed by increasing volcanic activity as indicated by pyroclastics of the F3 facies. The upper part of the Vučji Jarek mb. interfingers with the lower part of the Čemernica mb. (Fig. 3B). The Čemernica mb. belongs to the middle part of the Macelj fm. and probably to the middle-late Eggenburgian. Its deposits partly interfinger with and overlie the glauconitic sandstones (F2) of the upper part of the Vučji Jarek mb. (Fig. 3B). They also transgressively cover the early Egerian marine Meljani fm. (Figs. 2 and 3B) that is characterized by littoral carbonate rocks overlain by prodelta marls and sandstone intercalations (AVANIĆ et al., 2018a,b). Deposits of the Čemernica mb. are overlain by the fan delta and shoreface conglomerates and sandstones of the late Eggenburgian Lipni Vrh mb. (Fig. 3B). These deposits represent 
the upper part of the Macelj fm. The conglomerates and sandstones intercalate within the upper part of the Čemernica mb. where they form a $10 \mathrm{~m}$ thick lens (Figs. 2 and 3B). Finally, the Macelj fm. terminates with tidal to subtidal sands, marls, bentonite clays and pyroclastics of the late Eggenburgian to the early Ottnangian Vrbno mb. (Fig. 3B) (AVANIĆ et al., 2018a).

Furthermore, the calcareous siltstones, silty sands, pyroclastics and gravels of the Ottnangian marine nearshore Bednja fm. cover the top of the Čemernica mb. (Figs. 2 and 3B) indicating the continuation of Early Miocene marine deposition in the HZB (AVANIĆ, 2012; AVANIĆ et al., 2018a). Geological mapping indicated that deposits of the Vučji Jarek and Čemernica members are thickest in the western part of the investigated area where they reach up to $400 \mathrm{~m}$ (Fig. 3B) suggesting high accommodation in the HZB. Their thickness decreases towards the east.

The vertical succession of the Vučji Jarek and Čemernica members indicates a gradual change from a more coarse-grained deposition into a more fine-grained deposition as a consequence of deepening of the environment from the shoreface into the offshore-transition zone. The subsequent coarse-grained deposits of the Lipni Vrh mb. reflect a new shallowing phase of the environment (Fig. 3B). So, deposits of the Macelj fm. indicate sea level changes and represent a marine transgressive-regressive sequence that formed during the Eggenburgian into the early Ottnangian. The sea level changes are not correlative with the eustatic sea level changes that indicate three 3rd order transgressive-regressive sequences in the early Miocene (sensu HARDENBOL et al., 1998).

\subsection{Regional correlation of the lithostratigraphic units}

Deposits of the Vučji Jarek and Čemernica members can be correlated with similar Eggenburgian deposits in the Central Paratethys. First of all, deposits of the Vučji Jarek mb. transgressively overlie older rocks that is a characteristic of the Central Paratethys realm where the erosional gap was frequently developed at the base of the Eggenburgian and the basal sediments reflect a transgressive pattern (RÖGL \& STEININGER, 1983; MANDIC et al., 2004; PILLER et al., 2007). Lithologically, deposits of the Vučji Jarek mb. and the Čemernica mb. are correlative with the Lower Miocene quartz sands, sandstones and conglomerates with sandy clay intercalations in the western prolongation of the HZB in NE Slovenia (BUSER, 1977; ANIČIĆ \& JURIŠA, 1984; JELEN \& RIFELJ, 2002), and with the lower Miocene deposits in NE Austria associated with the Eggenburgian Group (STEININGER \& SENES, 1971). Within the Eggenburgian Group, shallow marine sands of the Burgschleintz Formation with clayey sands and clays of the Kühnring Member (MANDIC \& STEININGER, 2003) can be correlated with deposits of the Macelj fm. and the Čemernica mb., respectively, from NW Croatia. Furthermore, there is a significant similarity of the Vučji Jarek and Čemernica members deposits with the glauconitic sandstones of the Eggenburgian Pétervására Sandstone Formation from the northeastern segment of the North Hungarian Bay. There, crossbedded sandstones interpreted as sandwaves indicated subtidal deposition with dominant ebb currents towards the north, similar to the Hrvatsko Zagorje Basin (SZTANÓ, 1995; SZTANÓ \& DE BOER, 1995; SZTANÓ \& JÓZSA, 1996; BÁLDI, 2009; SZÖCS \& HIPS, 2018). Moreover, the Alpine Foreland basins were also characterized by tidally controlled deposits in the Eggenburgian (ALLEN et al., 1985). The explosive volcanic activity in the Hrvatsko Zagorje Basin is another common characteristic that is correlative with the Central Paratethys in the Eggenburgian as the volcanism affected a large area of the realm (SLÁVIK et al., 1968; KALIČIAK et al., 1989; ROETZEL, 1994; NEHYBA \& ROETZEL, 1999; PAMIĆ et al., 2002; PÉCSKAY et al., 2006).

The correlation indicates that the development of the western-southwestern part of a restricted shallow epicontinental sea of the Hrvatsko Zagorje Basin, dominated by siliciclastic deposition and strong influence of tidal currents, fits with the general characteristics of the Central Paratethys in the Eggenburgian. The palaeogeographic position of the study area (sensu POPOV et al., 2004; HARZHAUSER \& PILLER, 2007; KOVÁČ et al., 2017) suggests deposition in the relatively shallow southern bay of the Central Paratethys in the Eggenburgian, i.e. in the Hrvatsko Zagorje Bay.

\section{CONCLUSIONS}

1. The Eggenburgian-early Ottnangian Macelj formation consists of four members: the Vučji Jarek mb., the Čemernica mb., the Lipni Vrh mb. and the Vrbno mb.

2. The Vučji Jarek mb. is composed of three facies that formed in a shallow sea. The Facies of horizontally bedded sandstones (F1) reflects deposition on the foreshore to the upper shoreface under the tidal influence. The Facies of horizontally and cross-bedded glauconitic sandstones (F2) belongs to the foreshore to the shoreface zone strongly affected by tides. The Facies of horizontally and cross-bedded pyroclastics (F3) formed in the shoreface.

3. The Čemernica mb. is represented by the Facies of structureless clayey-silty sands (F4) of the offshore-transition zone. Deposition was influenced by tides in the Hrvatsko Zagorje Bay that represented a marginal sedimentary basin of the Central Paratethys Sea.

4. K-Ar dating of separated glauconite mineral fractions yielded an early Eggenburgian age of the Vučji Jarek mb. glauconitic sandstones $(19.2 \pm 0.64 \mathrm{Ma})$ that confirms biostratigraphic analyses.

5. Deposits of the Macelj fm. represent a marine transgressiveregressive sequence that is not correlative with the eustatic sea level changes in the Early Miocene.

6. The erosional gap in the base of the Vučji Jarek mb., the prevalence of siliciclastics, the shallow marine environment, the influence of tides on the deposition and the synsedimentary volcanic activity, all fit the general characteristics of the Central Paratethys Sea and its palaeogeography in the Eggenburgian.

7. We propose formalizing the four members described within this paper, as well as the Macelj formation itself.

\section{ACKNOWLEDGEMENT}

This research is a part of the long-term project Basic Geological Map of the Republic of Croatia at the scale of 1:50.000 financed by the Ministry of Science of Croatia (MZO; project number 1811811096-1093) and the Croatian Geological Survey. It was also supported by the European Union and the State of Hungary and co-financed by the European Regional Development Fund (GINOP-2.3.2-15-2016-00009 'ICER'), in part by the Croatian Science Foundation under the project IP-2019-04-7042 (SEDBAS) and by the University of Zagreb. Special thanks to Jožica ZUPANIČ and the Neogene mapping team (Antun ŠIMUNIĆ, Ivan HEĆIMOVIĆ, Marijan KOVAČIĆ, Davor VRSALJKO and Damir SLOVENEC) for their support during this research. Our thanks also go to Oleg MANDIC for kindly checking the fossils 
list. The technical support of Nenad KURTANJEK, Ivo SUŠA and Marko BUDIĆ is gratefully acknowledged. We thank Mirka TRAJANOVA and the anonymous reviewer for their thoughtful reviews.

\section{REFERENCES}

ALLEN, J.R.L. (1968): Current ripples.- North-Holland, Amsterdam, 433 p.

ALLEN, J.R.L. (1980): Sand waves: a model of origin and internal structures.-Sediment. Geol., 26, 281-328. doi: 10.1016/0037-0738(80)90022-6

ALLEN, J.R.L. (1984): Sedimentary Structures: Their Character and Physical Basis.Developments in Sedimentology, 30A, Elsevier, 593 p.

ALLEN, P.A., MANGE-RAJETZKY, M., MATTER, A. \& HOMEWOOD, P. (1985): Dynamic palaeogeography of the open Burdigalian seaway, Swiss Molasse basin.Eclogae Geol. Helv., 78, 351-381.

ALJINOVIĆ, D., JURAK, V. \& KOMPAR, D. (2003): Compositional variations and origin of glauconite-bearing sandstones (Macelj formation, NW Croatia).- In: VLAHOVIĆ, I. (ed.): 22nd IAS Meeting of Sedimentology, Opatija. Abstracts Book, Zagreb, p. 5.

ANIČIĆ, B. \& JURIŠA, M. (1984): Osnovna geološka karta SFRJ 1:100.000, list Rogatec L 33-68 [Basic Geological Map of SFRY 1:100000, Rogatec sheet-in Slovenian].Geološki zavod, Ljubljana, Geološki zavod, Zagreb, Savezni geološki zavod, Beograd.

ANIČIĆ, B. \& JURIŠA, M. (1985): Osnovna geološka karta SFRJ 1:100.000. Tolmač za list Rogatec L33-68 [Basic Geological Map of SFRY 1:100000, Geology of the Rogatec sheet - in Slovenian].- Geološki zavod Ljubljana in Geološki zavod Zagreb, Savezni geološki zavod, Beograd, $76 \mathrm{p}$.

ANIČIĆ, B., OGORELEC, B., KRALJ, P. \& MIŠIĆ, M. (2002): Litološke značilnosti tercijarnih plasti na Kozjanskem. Lythology of Tertiary beds in Kozjansko, Eastern Slovenia.- Geologija, 45, 213-246.

ASHLEY, G.M. (1990): Classification of large - scale subaqueous bedforms: A new look at an old problem.- J. Sediment. Petrol., 60, 160-172.

AVANIĆ, R. (2012): Litostratigrafske jedinice donjeg miocena sjeverozapadne Hrvatske [Lower Miocene lithostratigraphic units from north-western Croatia - in Croatian].Unpubl. PhD Thesis, Faculty of Science, University of Zagreb, 162 p.

AVANIĆ, R., PÉCSKAY, Z., WACHA, L. \& PALINKAŠ, L. (2005): K-Ar dating of glauconitic sediments in Macelj Mt. (NW Croatia).- In: VELIĆ, I., VLAHOVIĆ, I. \& BIONDIĆ, R. (eds.): 3. Hrvatski geološki kongres, Opatija, Knjiga sažetaka, Zagreb, 5-6.

AVANIĆ, R., ŠIMUNIĆ, AN., HEĆIMOVIĆ, I., KOVAČIĆ, MA., MARKOVIĆ, S., GRGASOVIĆ, T., KUREČIĆ, T., SLOVENEC, D. \& VRSALJKO, D. (2015): Osnovna geološka karta RH 1:50000, List Trakošćan (Ptuj 2) [Basic Geological Map of RH 1:50000, Geology of the Trakošćan (Ptuj 2) sheet - in Croatian].- Hrvatski geološki institut, Zavod za geologiju, Zagreb.

AVANIĆ, R, KOVAČIĆ, M., PAVELIĆ, D. \& PEH, Z. (2018a): The Neogene of Hrvatsko Zagorje.- In: TIBLJAŠ, D., HORVAT, M., TOMAŠIĆ, N., MILEUSNIĆ, M. \& GRIZELJ, A. (eds.): $9^{\text {th }}$ Mid-European Clay Conference, Conference book - Field Trip Guide book, Zagreb, 128-129.

AVANIĆ, R., ŠIMUNIĆ, AN. \& PEH, Z. (2018b): Geology of the Croatian Zagorje Region.- In: RMAN, N., MARKOVIĆ, T. \& BRENČIĆ, M. (eds.): 5. Slovenski geološki kongres, Post congress field trip book, Ljubljana, p. 35.

BÁLDI, T. (1969): The Oligo-Miocene stages of the Middle Paratethys area and the Egerian formations in Hungary.- Ann. Univ. Sci., Sect. Geol., 12, 19-28.

BÁLDI, T. (1980): A korai Paratethys története.- Földtani Közlöny, 110, 456-472.

BÁLDI, T. (2009): Kelet-mátrai oligo-miocén rétegsorok paleoklimatológiai és ökológiai elemzése - Az antarktiszi oligo-miocén jégtakaró változásainak nyomai a Paratethysben.- Földtani Közlöny, 139, 131-150 (in Hungarian).

BALOGH, K. (1985): K/Ar dating of Neogene volcanic activity in Hungary. Experimental technique, experience and methods of chronological studies.-ATOMKI Reports D/1, Debrecen, 277-288.

BESSON, G. \& DRITS, V.A. (1997): Refined relationships between chemical composition of dioctahedral fine-grained mica minerals and their infrared spectra within the $\mathrm{OH}$ stretching region. Part I: Identification of the $\mathrm{OH}$ stretching bands.- Clay. Clay. Miner., 45, 158-169. doi: 10.1346/CCMN.1997.0450204

BOURGEOIS, J. (1980): A transgressive shelf sequence exhibiting hummocky stratification: the Cape Sebastian Sandstone (Upper Cretaceous), southwestern Oregon.- J. Sediment. Petrol., 50, 681-702. doi: 10.1306/212F7AC2-2B24-11D78648000102C1865D

BOURGEOIS, J. \& LEITHOLD, E.L. (1984): Wave-worked conglomerates - depositional processes and criteria for recognition.- In: KOSTER, E.H. \& STEEL, R.J. (eds.): Sedimentology of Gravels and Conglomerates. Mem. Can. Soc. Petrol. Geol., 10, 331-343, Canada.
BRLEK, M., IVEŠA, LJ., BRČIĆ, V., SANTOS, A., ĆORIĆ, S., ŠPIŠIĆ, M., AVANIĆ, R., DEVESCOVI, M., PEZELJ, Đ., MIŠUR, I., MIKNIĆ, M. \& JOHNSON, M. E. (2018): Rocky-shore unconformities marking the base of Badenian (Middle Miocene) transgression on Mt. Medvednica basement (North Croatian Basin, Central Paratethys).- Facies, 64, 1-22. doi: 10.1007/s10347-018-0537-0

BRLEK, M., KUTTEROLF, S., GAYNOR, S., KUIPER K., BELAK, M., BRČIĆ, V., HOLCOVÁ, K., WANG, K.-L., BAKRAČ, K., HAJEK-TADESSE, V., MIŠUR, I., HORVAT, M., ŠUICA, S. \& SCHALTEGGER, U. (2020): Miocene syn-rift evolution of the North Croatian Basin (Carpathian-Pannonian Region): new constraints from Mts. Kalnik and Požeška gora volcaniclastic record with regional implications.- Int. J. Earth. Sci., 109, 2775-2880.

BUSER, S. (1977): Osnovna geološka karta SFRJ 1:100.000, list Celje L33-67 [Basic Geological Map of SFRY 1:100000, Celje sheet - in Slovenian].--Geološki zavod, Ljubljana, Savezni geološki zavod, Beograd.

CAS, R.A.F. \& WRIGHT, J.V. (1995): Volcanic Successions - Modern and Ancient.Chapman \& Hall, 528 p. doi: 10.1007/978-94-009-3167-1

CHEEL, R.J. (1990): Flow, sediment transport and bedform dynamics over the transition from dunes to upper-stage plane beds: implications for the formation of planar laminae.- Sedimentology, 37, 549-553. doi: 10.1111/j.1365-3091.1990.tb00155.x

CLIFTON, H.E., HUNTER, R.E. \& PHILLIPS, R.L. (1971): Depositional structires and processes in the non-barred hugh-energy nearshore.- J. Sediment. Petrol., 41, 651-670.

ĆORIĆ, S., PAVELIĆ, D., RÖGL, F., MANDIĆ, O., VRABAC, S., AVANIĆ, R., JERKOVIĆ, L. \& VRANJKOVIĆ, A. (2009): Revised Middle Miocene datum for initial marine flooding of North Croatian Basins (Pannonian Basin System, Central Paratethys).- Geol. Croat., 62/1, 31-43.

DALRYMPLE, R.W. (1992): Tidal Depositional Systems.- In: WALKER, R.G. \& JAMES, N.P. (eds.): Facies Models: Response to Sea Level Change. Geol. Assoc. Canada, Newfoundland, 195-218.

DASHTGARD, S.E., MACEACHERN, J.A., FREY, S.E. \& GINGRAS, M.K. (2012): Tidal efects on the shoreface: Towards a conceptual framework.- Sediment. Geol., $279,42-61$.

DESJARDINS P.R., BUATOIS, L.A., PRATT, B.R. \& MÁNGANO, M.G. (2012): Sedimentological-ichnological model for tide-dominated shelf sandbodies: Lower Cambrian Gog Group of western Canada.- Sedimentology, 59, 1452-1477. doi: 10.1111/j.1365-3091.2011.01312.x

FODOR, L., GERDES A., DUNKL, I., KOROKNAI, B., PÉCSKAY, Z., TRAJANOVA, M., HORVÁTH, P., VRABEC, M., JELEN, B., BALOGH, K. \& FRISCH, W. (2008): Miocene emplacement and rapid cooling of the Pohorje pluton at the AlpinePannonian-dinaridic junction, Slovenia.- Swiss J. Geosci., 101, 255-271. doi: $10.1007 / \mathrm{s} 00015-008-1286-9$

FODOR, L. (2019): Results, problems and future tasks of palaeostress and fault-slip analyses in the Pannonian Basin: the Hungarian contribution.- Földtani Közlöny, 149, 297-326. doi: 10.23928/foldt.kozl.2019.149.4.297

GOLUB, LJ. \& BRAJDIĆ, V. (1969): Piroklastične stijene kod Donjeg Jesenja (Hrvatsko zagorje) [Pyroclastic rocks from the Donje Jesenje (Hrvatsko Zagorje) - in Croatian with English summary].- Geol. vjesnik, 22, 411-422.

GORJANOVIĆ-KRAMBERGER, D. (1904a): Geologijska prijegledna karta Kraljevine Hrvatske-Slavonije 1:75.000, list Rogatec-Kozje [Overwiev Geological Map of Kingdom of Croatia and Slavonia 1:75000, Rogatec-Kozje sheets - in Croatian] Zona 21, Col. XII.-Naklada Kraljevske zemaljske vlade, Odjel za unutarnje poslove, Zagreb.

GORJANOVIĆ-KRAMBERGER, D. (1904b): Geologijska prijegledna karta Kraljevine Hrvatske-Slavonije 1:75000. Tumač za list Rogatec-Kozje [Overwiev Geological Map of Kingdom of Croatia and Slavonia 1:75000, Geology of the Rogatec-Kozje sheet - in Croatian].- Naklada Kraljevske zemaljske vlade, Odjel za unutarnje poslove, Zagreb, $25 \mathrm{p}$.

GRUNERT, P., SOLIMAN, A., ĆORIĆ, S., ROETZEL, R, HARZHAUSER, M. \& PILLER, W.E. (2012): Facies development along the tide-influenced shelf of the Burdigalian Seaway: An example from the Ottnangian stratotype (Early Miocene, middle Burdigalian).- Mar. Micropaleontol., 84-85, 14-36. doi: 10.1016/j.marmicro.2011.11.004

HARDENBOL, J., THIERRY, J., FARLEY, M.B., JACQUIN, T., DE GRACIANSKY, P.-C. \& VAIL, P. (1998): Mesozoic and Cenozoic sequence chronostratigraphic framework of European basins.-In: GRACIANSKY, P.C., HARDENBOL, J., JACQUIN, T. \& VAIL, P.R. (eds.): Mesozoic and Cenozoic Sequence Stratigraphy of European Basins. SEPM Spec. Publ., 60, Charts 1-8. doi: 10.2110/pec.98.02.0003

HARZHAUSER, M. \& PILLER, W.E. (2007): Benchmark data of a changing sea - Palaeogeography, palaeobiogeography and events in the Central Paratethys during the Miocene.-Palaeogeogr. Palaeoclimatol. Palaeoecol., 253, 8-31. doi: 10.1016/j.palaeo.2007.03.031

HARZHAUSER, M., THEOBALT, D., STRAUSS, P., MANDIC, O., CARNEVALE, G. \& PILLER, W.E. (2017): Miocene biostratigraphy and paleoecology of the Mistel- 
bach Halfgraben in the northwestern Vienna Basin (Lower Austria).- Jb. Geol. B.A., $157,57-108$.

HOWARD, J.D. \& REINECK, H.E. (1981): Depositional facies of high-energy beach-tooffshore sequence: comparison with low-energy sequence.- AAPG Bull., 65, 807-830.

JELEN, B. \& RIFELJ, H. (2002): Stratigraphic structure of the B1 Tertiary tectonostratigraphic unit in eastern Slovenia.- Geologija, Ljubljana, 45, 115-138. doi: 10.5474/ geologija.2002.010

KALIČIAK, M., KONEČNÝ, V. \& LEXA, J. (1989): Struktúry a v 'yvoj neogénnych vulkanitov Slovenska vo vzt'ahu k blokovej tektonike.- Geol. Práce, Spr. 88, 79-103.

KUMAR, N. \& SANDERS, J.E. (1976): Characteristics of shoreface storm deposits: modern and ancient examples.- J. Sediment. Petrol., 46, 145-162.

KORBAR, T., AVANIĆ, R., BAKRAČ, K., BELAK, M., BERGANT, S., BRČIĆ, V., BRLEK, M., FUČEK, L., GRGASOVIĆ, T., GRIZELJ, A., HALAMIĆ, J., HEĆIMOVIĆ, I., HORVAT, M., JAMIČIĆ, D., KOCH, G., MATIČEC, D., OŠTRIĆ, N., PALENIK, D., SLOVENEC, D. \& ŠORŠA, A. (2012): Upute za izradu Osnovne geološke karte Republike Hrvatske M 1:50 000.- Hrvatski geološki institut, Zagreb, 132 p.

KOVÁČ, M., HUDÁČKOVÁ, N., HALÁSOVÁ, E., KOVÁČOVÁ, M., HOLCOVÁ, K., OSZCZYPKO CLOWES, M., BÁLDI, K., LESS, GY, NAGYMAROSY, A., RUMAN, A., KLUČIAR, T. \& JAMRICH, M. (2017): The Central Paratethys palaeoceanography: a water circulation model based on microfossil proxies, climate, and changes of depositional environment.-Acta. Geol. Slov., 9, 75-114.

KOVÁČ, M., HALÁSOVÁ, E., HUDÁČKOVÁ, N., HOLCOVÁ, K., HYŽNÝ, M., JAMRICH, M. \& RUMAN, A. (2018): Towards better correlation of the Central Paratethys regional time scale with the standard geological time scale of the Miocene Epoch.- Geol. Carpath., 69, 283--300. doi: 10.1515/geoca-2018-0017

LEITHOLD, E.L. \& BOURGEOIS, J. (1984): Characteristics of coarse-grained sequences deposited in nearshore, wave-dominated environments - examples from the Miocene of south-west Oregon.- Sedimentology, 31, 749-775. doi: 10.1111/j.1365-3091.1984.tb00884.x

LONGHITANO, S., CHIARELLA, D. \& MUTO, F. (2014): Three-dimensional to twodimensional cross-strata transition in the lower Plesitocene Catanzaro tidal strait transgressive succession (southern Italy).- Sedimentology, 61, 2136-2171. doi: $10.1111 /$ sed. 12138

MALVIĆ, T. (2012): Review of Miocene shallow marine and lacustrine depositional environments in Northern Croatia.- Geol. Q., 56, 493-504. doi: 10.7306/gq.1035

MANDIC, O. \& STEININGER, F.F. (2003): Computer-based mollusc stratigraphy - a case study from the Eggenburgian (Lower Miocene) type region (NE Austria).- Palaeogeogr. Palaeoclimatol. Palaeoecol., 197, 263-291. doi: 10.1016/S00310182(03)00469-3

MANDIC, O., HARZHAUSER, M. \& ROETZEL, R. (2004): Taphonomy and sequence stratigraphy of spectacular shell accumulations from the type stratum of the Central Paratethys stage Eggenburgian (Lower Miocene, NE Austria).- Cour. Forsch. Inst. Senckenberg, 246, 69-88.

MÁRTON, E., PAVELIĆ, D., TOMLJENOVIĆ, B., AVANIĆ, R., PAMIĆ, J. \& MÁRTON, P. (2002): In the wake of a counterclockwise rotating Adriatic microplate: Neogene paleomagnetic results from northern Croatia.- Int. J. Earth Sci., 91, 514-523. doi: 10.1007/s00531-001-0249-4

MÁRTON, E., JELEN, B., TOMLJENOVIĆ, B., PAVELIĆ, D., POLJAK, M., MÁRTON, P., AVANIĆ, R. \& PAMIĆ, J. (2006): Late Neogene counterclockwise rotation in the SW part of the Pannonian Basin.- Geol. Carpath., 57, 41-46.

McPHIE, J., DOYLE, M. \& ALLEN, R. (1993): Volcanic Textures.- Hobart Tas., Centre for Ore Deposits and Exploration Studies, University of Tasmania, 196 p.

NEHYBA, S. \& ROETZEL, R. (1999): Lower Miocene volcaniclastics in South Moravia and Lower Austria.- Jahrb. Geol., Bund., 141, 473-490.

NIO, S.D. \& YANG, C.S. (1991): Diagnostic attributes of clastic tidal deposits: a review.In: SMITH, D.G., REINSON, G.E., ZAITLIN, B.A. \& RAHMANI, R.A. (eds.): Clastic Tidal Sedimentology. Mem. Can. Soc. Petrol. Geol., 16, 3-28.

ODIN, G.S. (1982): How to measure glaucony ages.- In: ODIN, G.S. (ed.): Numerical Dating in Stratigraphy, John Wiley \& Sons, New York, 387-403.

ODIN, G.S. \& DODSON, M.H. (1982): Zero isotopic age of glauconites.- In: ODIN, G.S. (ed.): Numerical Dating in Stratigraphy, John Wiley \& Sons, New York, 277-305.

ODIN, G.S. \& FULLAGAR, P.D. (1988): Geological significance of the glaucony facies.In: ODIN, G.S. (ed.): Green marine clays. Developments in Sedimentology, Elsevier, Amsterdam, 45, 295-332.

PAMIĆ, J., McKEE, E., BULLEN, T.D. \& LANPHERE, M. (1995): Geochronology and Petrology of Tertiar volcanic associations from the southern parts of the Pannonian Basin.- Int. Geol. Revi., 37, 259-283.
PAMIĆ, J., BALEN, D. \& HERAK, M. (2002): Origin and geodynamic evolution of Late Paleogen magmatic associations along the Periadriatic-Sava-Vardar magmatic belt.Geodin. Acta, 15, 209-231.

PAVELIĆ, D. (2001): Tectonostratigraphic model for the North Croatian and North Bosnian sector of the Miocene Pannonian Basin System.- Basin Res., 13, 359-376.

PAVELIĆ, D. \& KOVAČIĆ, M. (2018): Sedimentology and stratigraphy of the Neogene rift-type North Basin (Pannonian Basin System, Croatia): A review.- Mar. Petrol. Geol., 9, 455-469. doi: 10.1016/j.marpetgeo.2018.01.026

PÉCSKAY, Z., LEXA, J., SZAKÁCS, A., SEGHEDI, I., BALOGH, K., KONEČNÝ, V., ZELENKA, T., KOVACS, M., PÓKA, T., FÜLÖP, A., MÁRTON, E., PANAIOTU, C. \& CVETKOVIĆ, V. (2006): Geochronology of Neogene-Quaternary magmatism in the Carpathian arc and Intra-Carpathian area: a review.- Geol. Carpath., 57, 511-530.

PILLER, W.E., HARZHAUSER, M. \& MANDIC, O. (2007): Miocene Central Paratethys stratigraphy - current status and future directions.- Stratigraphy, 4, 151-168.

PIPPÈRR, M. \& REICHENBACHER, B. (2009): Biostratigraphy and paleoecology of benthic foraminifera from the Eggenburgian "Ortenburger Meeressande" of southeastern Germany (Early Miocene, Paratethys).- N. Jb. Geol. Paläont. Abh., 254, 41-61. doi: 10.1127/0077-7749/2009/0003

PIPPÈRR, M., REICHENBACHER, B., KIRSCHER, U., SANT, K. \& HANEBECK, H. (2018): The middle Burdigalian in the North Alpine Foreland Basin (Bavaria, SE Germany) - a lithostratigraphic, biostratigraphic and magnetostratigraphic re-evaluation.- Newsl. Stratigr., 51, 285-309. doi: 10.1127/nos/2017/0403

POPOV, S.V., RÖGL, F., ROZANOV, A.Y., STEININGER, F.F., SHCHERBA, I.G. \& KOVÁC, M. (2004): Lithological-Paleogeographic maps of Paratethys. 10 Maps, Late Eocene to Pliocene.- Cour. Forsch.-Inst. Senckenberg, 250, 1-46.

RADOSLOVICH, E. (1962): The cell dimensions and symmetry of layer-lattice silicates. II. Regression relations.-Am. Mineral., 47, 617-636.

ROETZEL, R. (1994): Bericht 1993 über geologische Aufnahmen im Tertiär und Quartär im Raum Grafenberg - Maissau auf Blatt 22 Hollabrunn.- Jb. Geol. B.-A., 137/3, 435-438.

RÖGL, F. (1996): Stratigraphic correlation of the Paratethys Oligocene and Miocene.Mitt. Ges. Bergbaustud. Österr., 41, 65-73.

RÖGL, F. (1998): Paleogeographic considerations for Mediterranean and Paratethys seaways (Oligocene to Miocene).-Ann. Naturhist. Mus. Wien, 99A, 279-310.

RÖGL, F. \& STEININGER, F.-F. (1983): Vom Zerfall der Tethys zu Mediterran und Paratethys. Die Neogene Palaeogeographie und Palinspastik des zirkum-mediterranen Raumes.-Ann. Naturhist. Mus. Wien, 85, 135-163.

RÖGL, F. \& SPEZZAFERRI; S. (2003): Foraminiferal paleoecology and biostratigraphy of the Mühlbach section (Gaindorf Formation, Lower Badenian).- Ann. Naturhist. Mus. Wien 104A, 23-75.

SACHSENHOFER, R.F., JELEN, B., HASENHÜTLL, C., DUNKEL, I. \& RAINER, T. (2001): Thermal history of Tertiary basins in Slovenia (Alpine-Dinaride-Pannonian junction).- Tectonophysics, 334, 77-99. doi: 10.1016/S0040-1951(01)00057-9

SALVADOR, A. (1994): International Stratigraphic Guide - A guide to stratigraphic classification, terminology and procedure.- The International Union of Geological Sciences and The Geological Society of America, Boulder, 214.

SANT, K., PALCU, D.V., MANDIC, O. \& KRIJGSMAN, W. (2017): Changing seas in the Early-Middle Miocene of Central Europe: a Mediterranean approach to Paratethyan stratigraphy.- Terra Nova, 29, 273-281. doi: 10.1111/ter.12273

SLÁVIK, J. et al. (1968): Tectonics and subsequent volcanism in the western part of East Carpathians.- Int. Geol. Congress, Rep. of XXIII Sess., Praha, 2, 61-71.

SPEZZAFERRI, S., RÖGL, F., ĆORIĆ, S. \& HOHENEGGER, J. (2004): Paleoenvironmental changes and agglutinated foraminifera across the Karpatian/Badenian (Early/Middle Miocene) boundary in the Styrian Basin Austria, Central Paratethys).- In: M. BUBIK, M. \& KAMINSKI, M.A. (eds.): Proceedings VI International Workshop on Agglutinated Foraminifera. Grzybowski Foundation Special Publication, $8,423-459$.

STEIGER, R.H., \& JÄGER, E. (1977). Subcommission on geochronology: Convention on the use of decay constants in geo- and cosmochronology.- Earth Planet. Sci. Lett., 36, 359-362. doi: 10.1016/0012-821X(77)90060-7

STEININGER, F. \& SENES, J. (1971): M1 Eggenburgien. Die Eggenburger Schichtengruppe und Stratotypus. Chronostratigraphie und Neostratotypen.- Vydav. Slov. Akad. vied, 2, Bratislava.

SWIFT, D.J.P., HUDELSON, P.M., BRENNER, R.L. \& THOMPSON, P. (1987): Shelf construction in a foreland basin: storm beds, shelf sand bodies, and shelf-slope depositional sequences in the Upper Cretaceous Mesaverde Group, Book Clifs, Utah.Sedimentology, 34, 423-457.

SZŐCS, E. \& HIPS, K. (2018): Multiphase carbonate cementation in the Miocene Pétervására Sandstone (North Hungary): implications for basinal fluid flow and burial history.- Geol. Carpath., 6, 515-527. doi: 10.1515/geoca-2018-0030 
SZTANÓ, O. (1995): Palaeogeographic significance of tidal deposits: an example from an early Miocene Paratethys embayment, Northern Hungary.- Palaeogeogr. Palaeoclimatol. Palaeoecol., 113, 173-187. doi: 10.1016/0031-0182(95)00054-P

SZTANÓ, O. \& DE BOER, P.L. (1995): Basin dimensions and morphology as controls on amplification of tidal motions (the Early Miocene North Hungarian Bay).- Sedimentology, 42, 665-682. doi: 10.1111/j.1365-3091.1995.tb00399.x

SZTANÓ, O. \& JÓZSA, S. (1996): Interaction of basin-margin faults and tidal currents on nearshore sedimentary architecture and composition: a case study from the Early Miocene of northern Hungary.- Tectonophysics, 266, 319-341. doi: 10.1016/ S0040-1951(96)00196-5

ŠIMUNIĆ, AL., ŠIMUNIĆ, AN., PIKIJA, M. \& AVANIĆ, R. (1988): Utjecaj vulkanizma na sastav "maceljskih pješčenjaka" (sjeverozapadna Hrvatska).- In: VUJISIĆ, P. (ed.): Geološki glasnik Posebno izdanje. Knjiga VI. Zbornik radova VI skupa sedimentologa Jugoslavije, Cetinje, Titograd, 229-243.

ŠIMUNIĆ, AL., AVANIĆ, R. \& ŠIMUNIĆ, AN. (1990): „Maceljski pješčenjaci” i vulkanizam zapadnog dijela Hrvatskog zagorja (Hrvatska, Jugoslavija).- Rad Jugosl., akad. znan. umjetn., 449, 24, 179-194.

ŠIMUNIĆ, AN., PIKIJA, M., HEĆIMOVIĆ, I. \& ŠIMUNIĆ, AL. (1981): Osnovna geološka karta SFRJ 1:100.000. Tumač za list Varaždin L 33-69 [Basic Geological Map of SFRY 1:100000, Geology of the Varaždin sheet - in Croatian].- Institut za geološka istraživanja, Zagreb, Savezni geološki zavod, Beograd, 75 p.

ŠIMUNIĆ, AN., PIKIJA, M. \& HEĆIMOVIĆ, I. (1982): Osnovna geološka karta SFRJ 1:100.000, list Varaždin L 33-69 [Basic Geological Map of SFRY 1:100000, Varaždin sheet - in Croatian].- Institut za geološka istraživanja, Zagreb, Savezni geološki zavod, Beograd.

ŠIMUNIĆ, AN., AVANIĆ, R., ŠIMUNIĆ, AL. \& HEĆIMOVIĆ, I. (1995): Litostratigrafska raščlamba donjomiocenskih klastita u Hrvatskom zagorju.- In: VLAHOVIĆ, I., VELIĆ, I. \& ŠPARICA, M. (eds.): 1. Hrvatski geološki kongres, Opatija, Zbornik radova (Proceedings), Zagreb, 2, 581-584.
TADEJ, N., SLOVENEC, D., TIŠLJAR, J. \& INKRET, I. (1997): Glauconitic materials from Lower Miocene Macelj-Sandstones of the Hrvatsko Zagorje, North-Western Croatia.- Geol. Croat. 50, 17-25.

TIBLJAŠ, D. (1996): Zeoliti i drugi produkti alteracijskih procesa u oligocenskim i donjomiocenskim piroklastitima na širem području Macelja [Zeolites and other products of the alteration processes in the Oligocene and Early Miocene pyroclastic rocks from the Macelj area - in Croatian, with English summary].- Unpubl. $\mathrm{PhD}$ Thesis, Faculty of Science, University of Zagreb, 167 p.

TIBLJAŠ, D. \& ŠĆAVNIČAR, S. (1988): Mineraloško istraživanje klinoptilolita, plagioklasa i seladonita iz tufa Donjeg Jesenja u Hrvatskom Zagorju [Mineralogical investigations of clinoptilolite, plagioclase and celadonite in tuff from Donje Jesenje (Hrvatsko Zagorje)].- Geol. vjesnik, 41, 99-117.

TIBLJAŠ, D. \& ŠĆAVNIČAR, S. (2007): Nalazište zeolitnog tufa na području Krapine.- In: FILIPAN, T., TIŠMA, S. \& FARKAŠ, A. (eds.): Prirodni zeolitni tuf iz Hrvatske u zaštiti okoliša, Zagreb, 13-23.

TIŠLJAR, J. \& ŠIMUNIĆ, AL. (1978): Maceljski pješčenjaci (Točke 2 i 3).- In: BABIĆ, LJ. \& JELASKA,V. (eds.): Vodič ekskurzije III Skupa sedimentologa Jugoslavije. Hrvatsko geološko društvo, Zagreb, 37-42.

TOMLJENOVIĆ, B. \& CSONTOS, L. (2001): Neogene-Quaternary structures in the border zone between Alps, Dinarides and Pannonian Basin (Hrvatsko zagorje and Karlovac Basins, Croatia).- Int. J. Earth Sci., 90, 560-578. doi: 10.1007/ s005310000176

VELDE, B. \& ODIN, G.S. (1975): Further information related to the origin of glauconite.- Clay. Clay. Miner., 23, 376-381. doi: 10.1346/CCMN.1975.0230509

VISSER, M.J. (1980): Neap-spring cycles reflected in Holocene subtidal large-scale bedform deposits: a preliminary note.- Geology, 8, 543-546. doi: 10.1130/00917613(1980)8\%3C543:NCRIHS\%3E2.0.CO;2

WHITHAM, A.G. \& SPARKS, R.S.J. (1986): Pumice.- Bull. Volcanol., 48, 209-224. 